ISSN: $1782-2041$

DOI: $10.25518 / 1782-2041.1248$

\title{
Recensions (février 2021)
}

Vincent Blok, Heidegger's Concept of Philosophical Method. Innovating Philosophy in the Age of Global Warming, Routledge Studies in Twentieth-Century Philosophy, Vol. 47, London, Routledge, 2020, 309 pages. ISBN : 9780367418120. Prix : $115 £$.

The book raises the question about philosophical method in the age of global warming and climate change. Blok argues that we should ask about a method to access uncorrelated being, in order to understand our position on planet Earth at this crucial moment, where climate change, loss of biodiversity and overpopulation might threaten our survival:

The question about our place on Earth leads to reflections on the philosophical method to get access to the Earth, while the question about the method of philosophy leads to reflections on planet Earth as uncorrelated being. (p. 21)

He borrows the notion of uncorrelated being from Meillassoux (p. 103-105), who recently introduced this concept in a critique of phenomenology's analysis of being as being-for-us. The first question is what Earth as uncorrelated being means. Uncorrelated being refers to reality as uncorrelated to man and human thought and action, for instance as it existed before the appearance of man and will eventually continue to exist after man has disappeared. In so far as our understanding of reality always derives from the way we access it through our knowledge of it, reality should be considered correlated being. This epistemological correlation prevents an understanding of the two relata, and more precisely of Earth, outside of its relation with man. Meillassoux's speculative realism understands uncorrelated reality as mathematical. For a number of methodological reasons he explains in the course of the book, Blok does not agree, and he searches for a different concept of Earth as uncorrelated being. This leads in the end to an ontology of Earth's materiality. In that sense, 
the book can also be read as a critical discussion of speculative realism, and more precisely of Meillassoux's critique of Heidegger, which Blok refutes.

But why should we want or need to access Earth as uncorrelated being, if that would be at all possible? Why would it be important for philosophy to understand Earth this way? The need for a reflection on uncorrelated being is urgent in our time, Blok claims. He even states that the task of philosophical thinking is to think uncorrelated being, that is the thing in itself outside the human (note 46, p. 125), in order to clarify man's position in this being. Modern time is characterized by an indifference towards being and a pre-occupation with beings as useful objects in the age of technology. This is the world (in the Heideggerian sense) we live in, in which everything is made serviceable for humans. This way of disclosing being, which we, according to a Heideggerian understanding, do not master ourselves, but is a specific epochal emergence of being in which we take part, has disastrous consequences for our being-in-the-world itself. It threatens our proper conditions of survival. So we need to enter a new way of being-in-the-world. In short, we need a new world. But this depends on how we relate to Earth. In order to change our being-inthe-world and hence to adopt a different attitude towards reality, we need to understand the conditions of possibility of such a change, and this requires us to understand the relation between the world we live in now and what founds it. So paradoxically enough, Blok seems to contend that our incapacity to understand Earth as uncorrelated being prevents us from understanding and eventually changing our place on it. This is the first brain teaser Blok's analysis presents to the reader.

The third question is what Earth means. How can we conceptualize Earth as uncorrelated being? For Blok, the crisis of contemporary philosophy consists precisely in a lack of interest in philosophical method to access uncorrelated being. This is a reminder of Husserl's plea and search for philosophy as a rigorous science a century ago, although the nature of the crisis is different from what he diagnosed it to be in his time. This lack is diagnosed in speculative realism (Meillassoux), object-oriented ontology (Harman) and ecological realism (Morton) (Introduction). Blok addresses this question about philosophical method through a critical engagement with Heidegger's thinking. Heidegger can guide us here because he considers the question of how we can have access to the meaning of the facticity of the correlation between being and thinking (understanding of being) as the central problem of phenomenology. Uncorrelated being beyond the correlation contains the meaning of this correlation. So the question is whether Heidegger's method of philosophy provides access to uncorrelated being. Blok offers in the first part of the book under the title "Analysis" a new interpretation of Heidegger's philosophical 
method in the light of postmodernism (Derrida) and speculative realism. This leads to an extensive discussion of Heidegger's criticism of the theoretical attitude characteristic of Husserl's phenomenology and of his innovation of philosophical method as hermeneutic philosophy (Chapter 1), of Heidegger's method of questioning (Chapter 2), of the 'religious' character of his philosophical method (Chapter 3) and of his concept of philosophical method as explorative confrontation (Auseinandersetzung) (Chapter 3). The discussion of these topics is a substantial contribution to Heidegger scholarship, but it is not always clear what the coherence between this different aspects is.

Blok explains how Heidegger radically changed the method of questioning typical of philosophy. Heidegger questioned and rejected the traditional metaphysical guiding question about the being of beings and articulated the grounding question about the truth of being, which he identifies as a-lètheia. Philosophical thought should reflect on the facticity of the correlation of being and thinking and try to uncover its sense or meaning. The method for this reflection is found in the exploration of questioning as a particular correlation between being and thinking. Although this method provides access to the correlation, it does not provide direct access to the truth of being because of the inclusion of thinking in the correlation. Hence the basic question for Heidegger is how we have access to uncorrelated being beyond the correlation and which contains the meaning of this correlation (p. 114). Questioning the nature of (traditional) questioning, which is typical of Heidegger's method, thus leads to a reflection on concealed and hence uncorrelated being:

The correlation between being and thinking (understanding of being) is indeed the point of departure of his philosophical thought, but he in fact raises the question of the sense or meaning of being of this self-evident correlation, which itself is beyond understanding, that is, which concerns uncorrelated being. (p. 109)

Blok claims that this attests for the relevance of Heidegger's philosophy today, where it is necessary to conceptualize Earth as uncorrelated being. Yet Blok argues that Heidegger's method suffers from various defects, which disable him to conceptualize uncorrelated being. The most important of these defects is a kind of circularity (p. 25, 177, 255). This circularity is the result of the method Heidegger uses to approach the object of analysis. In that sense, his take on the phenomenon he is trying to analyze is biased by his very method. Blok enters into an intricate discussion in part 2 entitled "Critique", with Heidegger's analysis of the Will (Chapter 5), and of Art and poetry (Chapter 6 ) in order to substantiate this claim. As a result, he redefines in a post- 
Heideggerian sense, with reference to Gibson's affordance theory, the Will as a person's attentive responsiveness to the affordance of that which is willed, and not as our decision to will that which is willed (note $38 \mathrm{p}$. 195). The method used to do this, which is inspired by Heidegger, is called explorative confrontation:

This means that the concept of willing should be derived from the things themselves, and the only thing that is manifest is the willing relation between the one who wills and that which is willed in willing - the directedness towards something. (p. 177)

This rehabilitation of the concept of the will is important and necessary in contemporary philosophy, Blok claims, because it implies that willing is characterized by an interest in the other or world because of the mutual involvement of the one who wills (self) and that which is willed (other or world) (p. 176). World-interest is a main characteristic of and requirement for a philosophical method that wants to understand (Earth as) uncorrelated being. This concept of willing is a necessary prerequisite for the interrogative intention, the attentive responsiveness and creativity of a post-Heideggerian method, whose main objective is the search for a new world amidst the technological world of today.

Furthermore, Blok contends that in the end Earth "remains unconceptualized in Heidegger" (p. 272). He identifies four characteristics of Earth as uncorrelated being for Heidegger, one of which is Earth as origin of the world. But Earth is here only indirectly accessible through an acquaintance with that (the world) which is related to it in the sense of founded in it. Hence Blok concludes that " (...) although Heidegger acknowledges Earth as uncorrelated being (ontological level), he derives his understanding of it from the way in which he has access to it (epistemological level)" (p. 272). This means that although Earth as uncorrelated being is ontologically prior to the world, it is epistemologically later than our experience of the world. The characteristics of Earth are derived from those of the world. Also, Heidegger's method is characterized by what Blok calls an onto-centrism, that is, by a focus on being and an indifference regarding beings. This prevents Heidegger from accessing planet Earth as uncorrelated being, in the sense of an ontic-ontological condition for our being-in-the-world. Blok consequently asks for a revision of his philosophical method in order to articulate a post-Heideggerian understanding of Earth as an ontic-ontological condition of possibility.

In chapter 7 of the book "Philosophical Method as Earthbound Confrontation", Blok sets out to do this. Ontic phenomena like the emergence of planet 
Earth and of humanity on Earth have an ontological effect, namely the emergence of being, which presupposes the presence of Dasein. And so when humanity would disappear, this would also be an ontic event with ontological consequences (p. 274). The last paragraph of the book further details the characteristics of Earth as such an ontic-ontological condition of possibility. Blok calls this "the ontology of Earth's materiality as uncorrelated being" (p. 287). In the end, this complicated and difficult enumeration results in the conclusion that human existence needs the Earth, but not the other way round, and that a post-human, non-human world is thus possible. This seems a rather disappointing conclusion of such an intricate and challenging study of Heidegger's concept of philosophical method, which is actually the bulk and main interest of Blok's book. Whether the ontology of Earth's materiality as uncorrelated being is also a valuable contribution to eco-philosophy remains to be seen. Not only is the attribution of for instance responsive conativity to Earths materiality problematical because it seems to anthropomorphize material earthly processes. It is not clearly explained either how this ontology could found a new environmental ethics concerning our place on Earth as Blok claims it should.

The main interest of this book lies with the problem of method in order to answer the question how we should conceive of reality and our place in it. What are the basic characteristics of planet Earth and how should we behave towards it? Can we go on understanding the Earth as a material for our human needs or need we another insertion into our threatened environment? What are the conditions of possibility of our being-in-the-world and how could we respond to the threat of our survival on the basis of our understanding of them? Although these questions are certainly urgent in this time of global warming, one question continues to hang in the air throughout the book. Why is it necessary to adopt a post-Heideggerian discourse about Earth as uncorrelated being in order to reflect on our place on and attitude towards planet Earth, inorganic and organic nature, the environment and humanity in the age of global warming? We all know by now that we are heading towards a potential catastrophe if we do not rapidly and drastically change our way of being-in-theworld. But this is not a philosophical, it is a scientific insight. And it is also science that teaches us what options we have, if we don't want to end up with a dangerous change of the conditions of life as we live it now. How could philosophy and more precisely a philosophy inspired by Heidegger be of any help here? This question is the more relevant, because Heidegger understood the way we are in the world as the result of the emergence of being, which is not under human control. So changing our attitude to reality is not something we can do, but an Ereignis we have to wait for and be attentive to and open for. The idea that willing is also a matter of attentive responsiveness to the

\section{5}

Bull. anal. phén. XVII 3 (2021)

https://popups.uliege.be/1782-2041/ @ 2021 ULiège BAP 
possibility of another world seems promising here, and Blok should deepen this in the future.

As Blok remarks in his introduction, the three main contributions of the book are: A new interpretation of Heidegger's method, which is critically assessed, and thirdly a contribution to debates in contemporary environmental philosophy. This interpretation and discussion testifies of Blok's Heideggerscholarship and is an important contribution to the study of Heidegger. The more problematic contribution seems to me the articulation of a postHeideggerian concept of the Earth as uncorrelated being, that is the above mentioned ontology of Earth's materiality as uncorrelated being.

Peter Reynaert

Universiteit Antwerpen

Paul Humphreys, Emergence. A philosophical Account, New York, Oxford University Press, 2016, 288 pages. ISBN : 0190620323. Prix : 76,74€.

Cet ouvrage de P. Humphreys (University of Virginia) entreprend une explication et une défense du concept d'émergence. «Account », dans le titre, doit s'entendre au sens des critiques quand ils nous parlent de l'account qu'un bon musicien nous ferait d'une œuvre de Chopin : si l'œuvre est bien déjà là avant d'être jouée (comme le concept d'émergence), il s'agit d'opérer des choix qui orientent l'interprétation que l'on en rend.

L'émergence est un concept que l'on fait souvent remonter au System of Logic de J. S. Mill (voir Livre III, ch. 6 sur la composition des causes) ainsi qu'aux développements du British emergentism (C. D. Broad, Lloyd Morgan). Comme le montre l'ouvrage, l'émergence se produit faute de réductibilité d'une loi, d'une entité, d'une propriété, à des lois, propriétés, entités d'un autre domaine. En termes de niveaux (métaphore que l'ouvrage nous invite à abandonner), une propriété ou une entité d'un niveau supérieur B est émergente par rapport à un niveau initial A si elle n'est pas réductible à la simple combinaison additive de propriétés ou entités de A. Les critères pour parler d'émergence seraient donc (p. 26-36) : (1) une nouveauté par rapport à un domaine initial (B n'était pas prévisible à partir de A), (2) le fait que ce qui émerge soit en relation avec ce par rapport à quoi on le dit émerger (sans quoi tout émergerait de tout ce par rapport à quoi il est irréductible), (3) une autonomie de l'entité émergente (par ex. que les lois qui s'y appliquent ne proviennent pas du domaine dont elle émerge), (4) une forme de holisme (la propriété émergente

\section{6}

Bull. anal. phén. XVII 3 (2021)

https://popups.uliege.be/1782-2041/ @ 2021 ULiège BAP 
serait possédée par un système, comme tout émergeant des relations de ses parties). Pour Humphreys, la nouveauté et le fait qu'il y ait une relation entre ce qui est émergent et ce dont il émerge sont les seuls critères à être des conditions nécessaires.

Pour donner un exemple, selon la théorie que l'on adopte, les états mentaux pourraient être considérés comme émergents par rapport aux influx nerveux des neurosciences. On pourrait avoir de bonnes raisons de supposer les états mentaux irréductibles à la somme des propriétés des influx nerveux. Ils sont par ailleurs nouveaux, au sens où la propriété d'intentionnalité apparaît avec eux, et on peut - selon nos présupposés théoriques - les supposer reliés à des états corporels, par relation de survenance (supervenience) par exemple. Un autre exemple canonique (Mill, L. III, ch. 6) est l'eau. Les propriétés de l'eau comme molécule sont irréductibles à la somme des propriétés des atomes $\mathrm{H}$ et $\mathrm{O}$. Elles sont nouvelles et pourtant la molécule d'eau (du domaine de la chimie) est bien reliée aux atomes de la physique qui la composent.

Les choix de Humphreys peuvent étonner dans un premier temps. L'auteur préfère ne pas donner de poids aux théories qui feraient de l'émergence un phénomène inexplicable d'un point de vue rationnel et scientifique. Si l'auteur montre que le concept prend de l'importance au début du $20^{\mathrm{e}}$ siècle suite aux failles des modèles atomistes réductionnistes (en physique ou en logique), il insiste sur le fait que l'émergence n'est pas une notion vague ou mystique apparue pour combler leurs gouffres explicatifs faute de mieux. Au contraire, de nombreuses sciences fourniraient désormais des modèles élaborés de phénomènes émergents (par ex. les liaisons covalentes en chimie). L'ouvrage replace ces modèles dans la taxonomie du concept qu'il entend réaliser, et conclut de façon significative (ch. 7) sur l'émergence en sciences.

Un premier réflexe pourrait être de voir là une asymétrie : l'ouvrage se concentre sur des théories gagnantes, qui réussissent (corroborées d'un point de vue scientifique), en délaissant des théories de l'émergence appliquées aux états mentaux, aux qualia et à la conscience, car leurs cadres théoriques seraient moins clairs. En effet, sans vraiment mentionner la phénoménologie et la philosophie de l'esprit, absents de marque de l'ouvrage, Humphreys précise que les cadres théoriques des neurosciences et de la psychologie « restent sousdéveloppés (underdeveloped) en comparaison de la physique et de la chimie » (p. xix). Cependant, ce genre de remarque - problématique du point de vue de l'histoire de la philosophie - pourrait aussi être lu comme l'effet d'un choix méthodologique plus riche. Plutôt que de parler de l'émergence de la conscience ou des états mentaux, mystérieuse au sens où plusieurs auteurs (par ex. C. D. Broad, et plus récemment McLaughlin) ont eu tendance à valoriser 
une certaine inexplicabilité de ce type d'émergence (p. 217), Humphreys entend montrer que l'émergence existe dans les domaines de la physique. L'insistance sur les cas qu'il trouve en physique quantique ou en chimie a donc pour rôle de soutenir la thèse très forte de l'ouvrage selon laquelle il y a de l'émergence ontologique. Comme défense de l'émergence, l'ouvrage prend donc le parti de ne pas poser en détail la question de l'émergence par rapport à la conscience, pour prouver qu'il existe des phénomènes émergents réels, dans différents domaines de la physique. Humphreys revendique une posture qu'il qualifie de physicalisme non-fondamental et qui n'exclut pas a priori de nouveaux développements sur l'émergence pour des entités intentionnelles (ch. 6.1).

Si donc l'ouvrage entend nous fournir un cadre conceptuel pour comprendre l'émergence et en construire des théories cohérentes, c'est bien une thèse sur l'existence de phénomènes émergents qui est sans arrêt mise en avant. Humphreys dégage différents types d'émergence (ch. 1.7) : inférentielle, conceptuelle, ontologique. Chacun de ces types peut être soit synchronique (l'émergence a alors lieu à un instant $t$, abstrait, pris isolément), soit diachronique (l'émergence dépend d'un processus temporel pour se réaliser). L'émergence inférentielle revient à parler d'émergence quand on ne sait pas prédire à partir d'un système initial les propriétés émergentes, faute d'axiomes suffisants au niveau du système initial ou d'une intelligence capable de compiler toutes les étapes pour déduire la propriété émergente à partir des axiomes à disposition. L'émergence conceptuelle, relativement proche, se produit quand on a besoin de nouvelles représentations théoriques (concepts) et linguistiques pour décrire le phénomène émergent.

Ces deux types d'émergence ne correspondent pourtant pas encore à l'affirmation d'une réalité ontologique de l'émergence. L'émergence ontologique voit en l'émergence une propriété objective d'un phénomène du monde, indépendamment des lacunes des sujets connaissant. C'est de ce type d'émergence que Humphreys entend montrer l'existence, et il lui dédie la plus grande partie de son ouvrage (ch. 3). Des modèles atomistes, incapables de déduire les propriétés de l'eau à partir des atomes, pourraient encore s'accommoder de l'émergence inférentielle et conceptuelle: les entités fondamentales resteraient des atomes, au sens d'individus identiques et immuables. L'émergence ontologique apporte avec elle des questions plus épineuses : que se passe-t-il si l'entité émergente opère une causalité descendante (downward causation) sur les entités dont elle émerge ? Accepte-t-on la causalité descendante au prix d'abandonner une clôture causale des événements d'un domaine de la réalité ? L'ouvrage envisage de nombreux cas intéressants, comme l'émergence transformationnelle (des individus en interaction dans un domaine D peuvent se

\section{8}

Bull. anal. phén. XVII 3 (2021)

https://popups.uliege.be/1782-2041/ @ 2021 ULiège BAP 
transformer en nouveaux individus répondant à des principes d'un nouveau domaine D'), l'émergence comme fusion, etc.

Si l'ouvrage est lu comme une défense de l'émergence, se cantonner à prouver l'existence de formes d'émergence ontologique via des propositions scientifiques peut alors être un projet riche pour défendre, dans un second temps, que le fait de parler d'émergence pour la conscience, les qualia et la vie ne revient pas à utiliser un concept creux. Certes, on peut s'étonner de telles divergences d'approche, comme le fait J. Racine dans sa recension de Qu'estce que l'émergence? (O. Sartenaer, Vrin, 2018) : certains livres récents sur l'émergence se concentrent principalement sur la philosophie de l'esprit ou choisissent à l'inverse de laisser de côté la question de la conscience (ainsi, C. Gillett, Reduction and Emergence in Science and Philosophy, Cambridge, 2016). Mais les modèles proposés ici par Humphreys pourraient être repris et ne visent pas à exclure les entités intentionnelles, plutôt à nous inciter à les penser à nouveau, si c'est là le problème qui nous anime. C'est qu'au final, ce serait un très mauvais argument de supposer que la conscience ou nos états mentaux soient trop étranges et mystérieux que pour être des candidats à une émergence réelle, en tant qu'entités réelles : comme le souligne Humphreys, les entités de la physique fondamentale sont tout aussi étranges. Ce qui est rejeté par l'ouvrage, c'est le postulat que l'émergence d'une entité serait par principe inexplicable.

Jérôme Flas

Université de Liège

Sebastian Watzl, Structuring Mind. The Nature of Attention and How it Shapes Consciousness, Oxford, Oxford University Press, 2017, 336 pages. ISBN : 9780199658428. Prix : $52 £$.

Sebastian Watzl's Structuring Mind, The Nature of Attention and How it Shapes Consiousness, leaves in no abeyance the book's goal. Both branches of its pivotal contentions on the phenomenology of attention are broached: the first aims to provide a definition of attention closely interwoven with the second aim of elucidating its intimate interrelation to consciousness. Defended in a parallel manner, the ulterior ambition of the oeuvre fulfils itself as promised from the cover. The nature of attention mirrors shaped phenomenal consciousness, while, vice-versa, structured experiences reveal the nature of attention. 
The first part of Structuring Mind, expanding from Chapters 1-7, vindicates a definition of attention qua unified subject-level phenomenon employing three distinct, yet, reciprocally controlled methods. Firstly, it tackles scientific theories of attention stemming from cognitive psychology and neuroscience, according to which attention has been treated as everything from a perceptual filter to a feature integration mechanism and a regulator of biasedcompetition for brain resources. Secondly, the author discusses folk-psychology expressions, namely intelligible ways our quotidian talking and understanding of attention employ. Finally, he resorts to introspection as a traditionally philosophical method of acquiring knowledge of our own mental lives as well as those of others.

Watzl's pivotal strategy in indicating the intrinsic inadequacies of reductionist accounts- scientific and philosophical alike- consists in underscoring their failure to identify attention per se with a unified neuronal and/or computational process (or a set or property of such processes), able to account for its nature. Albeit their yielding reductive explanations of what underpins attention on the sub-subject level, the author claims that only on the subject level does attention earn a unified definition, dissipating on this basis even identifying reductionism about attention. Simultaneously, he refutes objections advanced by eliminativism and disunity views about attention that reject its fundamental character. In this perspective the author appeals to attention's significance for a subject's mental life.

Towards this end, in chapter 3 Watzl endeavours to establish the metaphysically fundamental kind of attention as a mental activity in which the subject engages. Nevertheless, this mental activity belongs to a quite particular sort, the sort that accommodates its multifarious effects as well as its diverse manifestations as intentional and unintentional, passive and active. Attention is an activity qua temporally open-ended shaped process, unlike states or events, which can unfold in different manners along the course. What is more, attention as a process is guided by two different factors: i. Psychological salience of a subject's mental states when unintentional and, ii. The executive control system of the subject when intentionally performed.

In Chapter 4, Watzl proceeds in elucidating what this very activity ultimately consists in. In that perspective, he vindicates a thesis, designated the Priority Structure View (page 70, henceforth P.S.V.) that equates attention to the activity of "creating, maintaining and changing a certain structure of the mind". The P.S.V. potentiates a unified view on different facets of attentional varieties in virtue of different priority structures in tandem with their integration with other aspects of mental life. Establishing the kind of activity attention is paves the way into demarcating the elements of priority structures and their 
structuring relation: the elements encompass the subject's mental states, events or processes related via relations of weak priority (a subject's mental state, event or process $\mathrm{x}_{1}$ is at least as much prioritized as is $\mathrm{x}_{2}$ ). At this argumentation stage, Watzl holds that the weak priority relation consists in an external relation, namely a relation not fully explained by the intrinsic properties of $\mathrm{x}_{1}$ and $\mathrm{x}_{2}$, a contention of utter importance for the second half of his exposition.

Chapter 5 ultimately deals with the emerging issue of the role of priority structures. The author vindicates a functionally organizational role of priority structures enabling behavioural decoupling. This view aligns with an influential functional alternative defended by Wayne $\mathrm{Wu}(\mathrm{Wu} 2014)$, to wit attention qua selection for action, yet differing in important points. Chapters 6 and 7 of Structuring Mind are dedicated to yielding subtle explications of the two prima facie disparate facets of attention, namely its being both passive and active. Having already consolidated that either due to psychological salience or due to the subject's executive control system, priority structures are primordially chiselled out of subject-level states, psychological salience-a mind's property(in the manner of evolution-guide of the attentional process), is further elaborated. Firstly, the occurrent subject-level states foster an imperatival content that dictates that $\mathrm{x}$ ought to be placed on top position of a priority structure. This imperative character permits to account for the variety of cues (mostly exogenous), the mode of attentional alteration it triggers as well as the connection between cues and attentional alteration. Moreover, this tenet permits the author to surmount four potential constraints: it yields reasons why the psychologically salient states are guiding, the motivational impact experienced by the subject, why they are mainly perceptual states and normatively neutral. With regards to guidance by executive control systems, Chapter 7 draws a specific analogy between intentional attention and intentional body movement, relying on a specific conception about agency as intentional self-controlled action.

Having seized a number of conclusions from demarcating the nature of attention, as activity of continuously creating, maintaining and changing priority structures, Watzl proceeds in the subsequent chapter into examining how this definition squares with the contribution of attention to phenomenal consciousness. His argumentation relies in the central observation that attention does make a phenomenal contribution beyond the ones exhausted by an appearance view proponent, to wit roughly the view that the phenomenal contribution of attention is exhaustively accounted for in terms of the effect on phenomenal qualities of conscious experience. What this view overlooks resides exactly in what the phenomenal contribution of attention fundamentally consists in, id est the curving of the experience's phenomenal structure into centre 
and periphery (the topic of Chapter 9), deflating its intimate connexion to its very nature. The advantages of this anti-deflationist view encompass a claim that not only is intuitive, but also refutes resistance stemming from the transparency thesis of experience as well as from the epistemic access to this phenomenal difference. In concert with this an epistemic argument is broached, articulated in two faces (page 179): the discriminability claim (1) (a subject can immediately and without external observation discern an attentional episode a from its replicated one with regards to its phenomenal properties b) and the discriminability phenomenology link (from the subject's ability to immediately discern $a$ from $b$ we infer that $a$ and $b$ are phenomenally different).

The appearance view is further confronted by delving into the rudiments of attention's phenomenal contribution. Since phenomenal experience appears not only replete of phenomenal qualities forming its parts but also structured, the question is irrevocably generated: how do phenomenal parts articulate themselves in conscious experiences? Exactly as articulated priority structures forming parts of conscious experiences partitioned more centrally or more peripherally than others. This partition constitutes the form of the subject's subjective perspective in the world of appearances: arrangement of conscious experience across the diptych centre-periphery. The ramifications of this contention, designated as phenomenal structuralism, are brought to the fore in the reminder of the book.

Abiding by phenomenal structuralism enables Watzl, along chapter 9, to expound an argument against a certain conception of attention as either mode of consciousness or determination of a mode of consciousness. Qualitative parts of conscious experiences connect to each other by virtue of an external centrality relation generating entire centrality systems. The entailed aforementioned significant parts compounded according to external (non derivable from the parts' intrinsic phenomenal qualities) weak priority relations exhibit both phenomenal unity and phenomenal entanglement. Centrality systems, drawing on a Gurwitschean inspiration to describe them, are often imbued by the centre-thematic field- margin partition. Having consolidated these rudimentary points, Watzl expounds the Phenomenal Construction Thesis pertaining to the phenomenal properties of a centrality system S, namely their being fully grounded in both the phenomenal qualities of qualitative parts composing $\mathrm{S}$ and the centrality relations between these parts. Refuting on the basis of phenomenal structuralism both phenomenal atomism (briefly the view that the existence of the whole is ultimately grounded on the existence of the parts) and phenomenal holism (referring to Elijah Chudnoff's stance on the matter (see Chudnoff 2013), who circumscribes it along these lines: the phenomenal properties of a qualitative part being such and such is partially grounded on the 
part's sustaining a very specific position in a centrality system), Watzl opts for a nuanced outlook of phenomenal construction that preserves the possibility of qualitative parts' existence independently of the centrality system they are embedded in.

In the next chapters (10 and 11) the rationale delivered along chapters 6 and 7 with regards to psychological salience and executive control systems guiding attention in unintentional and intentional manner respectively, expands with the perspective of explicating the corresponding arrangements of conscious experience upon attentional phenomenal differences. In agreement with the first part's conclusions, Watzl tackles the phenomenal salience of attentional conscious experience as the entertaining of a representation dictating in an imperative manner that a specific centrality structure ought to be achieved. Deemed in such dynamic a fashion, conscious experience incessantly reconfigures itself into centre-periphery aligned to priority structures occupying attention: whatever occupies attention is reflected in a relatively phenomenal central experiential position in consciousness. Since phenomenal salience entails a command to transit from an experiential state to another a contention admittedly inspired by Husserl's analyses of the structure of inner time consciousness- Watzl concludes that the fluidity of the stream of consciousness -temporally construed- is part and parcel with the passively guided attention overarched by phenomenal salience: antecedent experiences aim to subsequent ones, propelling reconfigurations of centrality structures.

In what follows, active guidance of attention is addressed in terms of agentive attention awareness of the phenomenal structure of experience: how a subject acquires knowledge of the phenomenal structure of her own experience relies largely on exerting attentional guidance, to wit on regulating priority and centrality structures. Addressing issues stemming from the debate on the sense of agency, the author extracts a notion of agentive attention awareness (the technical term designated "pushmi-pullyu" in the current dialogue, a notion of agentive awareness entailing both mind-to-world and world-to-mind directions of fit) empowering him to accommodate cases where attentional illusions ensue: the subject can introspectively form beliefs pertaining to the attentional structure of her experience by learning how to guide attention more subtly. In other words, the subject via agentive attention awareness is enabled to form beliefs about the fact that a guiding state is being prioritized over another, based on which she introspectively acquires knowledge of the attentional structure of consciousness.

Chapter 12 is dedicated to confronting a perplexing issue pertaining to the metaphysics of the attention-phenomenal consciousness relation. Watzl preliminarily reconstructs the background of the prevailing discussion rotating 
around a cardinal topic: is attention sufficient for consciousness? Is attention necessary for consciousness? Rejecting the validity of affirming the first point relying on experimental evidence of unconscious attention, he deems even its weaker position as focal sufficiency unsustainable (succinctly the claim that a mental state's occupation of the top priority position in a subject's priority system would suffice for phenomenal consciousness). The same obtains for the focal necessity claim, namely the claim that for a subject to be phenomenally conscious of a state, this state necessarily is the focus of attention. Nevertheless, the level of difficulty inherent in the overarching discussion magnifies itself when the thornier question of the relation between attention and accessible phenomenal consciousness ensues. Watzl proposes a solution reinforced by his comprehensive analysis of priority systems empowering an alternative framing of the problem along the following lines: does assuming the position of attention consisting in management of priority structure provides us with a better comprehension of the necessity that a mental state, process or activity be embedded as psychological part in a subject's priority system for it to be phenomenally conscious?

The conclusive part of the book advances a tenet on the essential attentional facet of consciousness irrespectively of its physicalist or dualist contentions. Watzl suggests that phenomenally distinct centrality relations in a subject's total centrality system sustain a viable story about three main features of consciousness: a unified, subjective and perspectival stance on the world. Unification, subjectivity and perspectivity emanate from the re-arranging of centrality structures that resist explanation purely in terms of phenomenal properties (pace the appearance view).

All in all, Watzl's endeavour strikes the reader immediately with its clairvoyance when underscoring shortages of standardised, influential scientific theories of attention as well as with the contribution to the unequivocal dialogue of the phenomenal character of conscious experience. Never does he omit the contemporary debate on the emerging issues, nor does he neglect to pay homage to pioneers expounding ideas to be nuanced in Structuring Mind. What the reader would anticipate is a somewhat more thorough circumscription of the interconnection between the external centrality relation and the phenomenal properties of the relevant qualitative states allocated a relatively more central or more peripheral position within a centrality system. Alternatively phrased, if both phenomenal atomism and phenomenal holism are to be refuted thanks to their structuralist alternative, a supplementary determination of the dependency relations between the catalyst and the reagents might prove beneficial. Do some phenomenal qualities of qualitative parts in a centrality system tend to "impose themselves" in more central positions? Do the former solicit 
a specific kind of "catalyst" to become integrated in a centrality structure? To my mind, insistence on the nature of external centrality relation (along with a parallel one on the weak external relation of priority structures) would further enhance one of the book's admirable analyses on the phenomenology of attention.

\section{References}

Wu Wayne (2014), Attention, Oxford, Routledge. Chudnoff Elijah (2013), "Gurwitsch's phenomenal holism", Phenomenology and the Cognitive Sciences, 12(3), 559-78.

Dimitra-Mimika Koulaxidi Université de Liège

Anna Donise, Critica della Ragione Empatica. Fenomenologia dell'altruismo e della crudeltà, Bologna, Il Mulino, 2019, 303 pages. ISBN : 8815285695. Prix $26 €$.

Dans le vaste paysage des émotions, l'empathie représente une notion complexe en raison des nombreuses définitions qui ont été proposées, depuis Lipps jusqu'à aujourd'hui. Se référant à la pensée phénoménologique, le nouveau livre d'Anna Donise aborde la question de front et assume un double objectif : 1) définir l'empathie et, ce faisant, 2) en saisir la portée normative. Le livre se divise en deux parties - l'une théorique et l'autre pratique — qui permettent au lecteur de pénétrer dans l'univers de l'empathie, un monde qui est simplement et fondamentalement humain.

L'ouvrage commence par une description exhaustive et méticuleuse du status quaestionis concernant la recherche sur l'empathie. L'autrice reconstruit les principales théories qui occupent la scène philosophique. Un point de référence important, que l'on retrouve à plusieurs reprises dans le texte, est Lipps, qui non seulement a été le premier à appliquer l'empathie en dehors du domaine esthétique, mais qui l'a de surcroît essentiellement définie comme notre manière d'être dans le monde. En suivant ce point de vue, l'autrice souligne la façon dont notre être dans le monde est, en réalité, connoté émotionnellement : la dimension émotionnelle devient ainsi une modalité d'être et de savoir, et elle détermine notre rapport avec la réalité. Cependant, l'approche lippsienne trouve sa limite dans l'accent excessif qu'elle porte au rôle de l'imitation et du niveau inconscient. Pour cette raison, Donise, même si elle part de Lipps, s'en 
écarte et adopte une approche phénoménologique, notamment en ce qui concerne l'attention accordée à la séparation que le Je et le Tu doivent maintenir au sein d'une expérience empathique authentique. Pour Husserl, dans la Paarung, je comprends que l'autre est un sujet au même titre que je le suis moi-même, un ici et maintenant, mais je comprends aussi que ses expériences me resteront étrangères et inaccessibles, car chaque individu représente un centre d'orientations différent. Cette asymétrie constitue un fossé insurmontable, mais qui assume le rôle important de préserver l'individualité : si la bilatéralité de la kinesthésie était étendue non seulement à mon corps, mais aussi à celui des autres, alors il n'y aurait qu'une seule conscience, un seul et unique Leib.

Le concept principal de l'ouvrage est celui de stratification. Donise élabore une véritable théorie de l'empathie entendue comme une émotion qui se déploie à travers différents niveaux. La référence à Husserl est inévitable. En effet, nous savons que, dans la vaste production husserlienne, il est possible de trouver de nombreuses définitions - ou tentatives de définition - de ce concept, depuis l'aperception simplement passive de l'animalité d'autrui (animalische Apperzeption), jusqu'à la compréhension active de ce que l'autre entend exprimer à travers ses mouvements.

Ce n'est d'ailleurs pas un hasard si une seconde référence, liée à la compréhension de la configuration émotionnelle, est le phénoménologue Max Scheler qui, dans Nature et formes de la Sympathie (1923), avait décrit une vie émotionnelle stratifiée. Le second chapitre est donc consacré à l'élaboration d'une théorie de l'empathie, une théorie qui parvient à combiner la nature polymorphe de ce concept avec ses nombreuses fonctions. En d'autres termes, Donise parvient à rendre justice aux différents niveaux que le terme général d'empathie inclut, des niveaux qui, inévitablement, s'entrecroisent. De manière cohérente avec l'approche schelerienne, le premier niveau affectif identifié est l'unipathie. Il s'agit du sentiment à la base de toute forme d'appréhension de l'autre, le fondement primordial de la donation d'autrui. Le deuxième niveau est celui de la contagion émotionnelle, dans lequel la dimension fusionnelle est toujours présente, mais uniquement au niveau du vécu en question, et non au niveau de l'identité des sujets impliqués.

La véritable distinction entre notre vécu et celui d'autrui s'opère au niveau de l'empathie, qui comprend à son tour trois niveaux : le niveau émotionnel (dans lequel on ressent l'expérience émotionnelle des autres, en la différenciant de la sienne, mais sans capacité d'évaluation immédiate), le niveau de l'identification (plus connoté cognitivement) et le niveau compréhensif-narratif. Dans ce dernier cas, des capacités d'imagination entrent en jeu, comme 
lorsque nous lisons un roman, qui permettent de nous identifier aux protagonistes. Tous ces niveaux sont nécessaires et déterminent la couche la plus élevée de la participation émotionnelle : la sympathie, qui prend place à titre d'expérience hybride, comprenant à la fois des éléments émotionnels et cognitifs, un «se sentir avec l'autre, en accueillant l'expérience, en y participant [...] Cela requiert de l'intérêt et du partage, disponibilité à accueillir et à participer à l'expérience d'autrui » (p. 134).

En effet, faire l'expérience de l'autre ne signifie pas s'identifier de temps en temps à des expériences individuelles, mais à un ego, à un corps dans l'espace doté d'une psyché, à un centre d'orientation semblable à moi mais, en même temps, complètement différent, parce qu'il dispose d'une histoire composée de vécus uniques et singuliers. La thèse de l'autrice devient de plus en plus claire : l'empathie est une condition nécessaire, mais pas suffisante pour ressentir de la sympathie et de la compassion, ou, en général, pour agir de manière éthique.

La deuxième partie du livre — plus « pratique » d'une certaine façon — vise précisément à démontrer cette thèse. Le troisième chapitre examine des cas tirés du monde de la psychopathologie, dans lesquels on peut observer de véritables pathologies de l'empathie. Dans la dépression mélancolique, le sujet se trouve incapable d'éprouver de l'empathie et de comprendre les vécus d'autrui. Même chose dans le cas du schizophrène : l'ego est tellement divisé et si peu structuré qu'il est impossible que les consciences fusionnent, fusion d'où auraient pu découler les sentiments de contagion, d'empathie, et finalement de sympathie. L'identité diachronique se trouve en effet corrompue : ne pouvant reconnaître son identité dans le temps, le sujet subira des troubles au niveau de la dimension narrative du soi qui l'empêcheront de résorber le fossé entre le soi et l'autre. Enfin, dans le cas de l'autisme, Donise nous montre comment la conception stratifiée de la vie affective réfute la théorie de Baron-Cohen selon laquelle l'autisme consiste en l'absence de capacité à lire dans l'esprit des autres, capacité qui, pour lui, correspond à l'empathie. Au contraire, l'approche de Donise nous permet de comprendre que le sujet avec autisme n'a pas du tout un quotient empathique faible : son malaise provient plutôt d'une sorte de super-empathie fusionnelle dont il ne peut pas s'échapper, faute de prendre ses distances et, par conséquent, de comprendre l'altérité.

L'exploration du monde de la psychopathologie permet d'aborder deux questions apparemment accessoires mais en réalité fondamentales si l'on parle de rencontre entre les sujets. La première concerne le rôle de l'empathie dans le domaine clinique, une notion largement débattue et contestée (pensons à la neutralité du psychanalyste). En se référant à Jaspers, Donise nous montre comment l'empathie peut s'avérer un outil fondamental, comme un organe 
(comme la vue ou le toucher) capable de percevoir des symptômes subjectifs. Même dans la description que fait Jaspers du bon psychiatre, différents niveaux d'empathie peuvent être identifiés : on va de l'observation des gestes et des expressions (un acte qui correspond à un sentir immédiat et non structuré, donc à une empathie émotionnelle) à l'entretien et à la collecte d'auto-descriptions du patient (des plans qui impliquent une compréhension plus cognitive, et l'usage de l'imagination). Une telle pratique psychiatrique, ou empathie thérapeutique, serait donc conforme à la description de l'empathie stratifiée proposée par l'autrice, soulignant également dans le contexte thérapeutique la centralité de l'intelligence émotionnelle, du sentir qui précède la compréhension ou, mieux encore, de la compréhension par le sentiment.

Mais que pouvons-nous comprendre en sentant? L'empathie nous permet-elle d'atteindre le noyau identitaire de l'autre ? Et quel est le rôle de l'altérité dans la dimension originaire du soi ? Le second régime de concepts étudié est précisément celui lié au problème du soi minimal : le noyau de la conscience, qui pour certains (Husserl en premier) n'est pas conditionné de manière intersubjective, alors que pour d'autres (dont Merleau-Ponty) il trouve précisément son origine dans sa relation à l'altérité. Dans ce cas également, l'adoption d'une vision stratifiée de la vie de la conscience permet de placer la mienneté à la base de la subjectivité, sans toutefois nier que le processus d'individuation prend naissance dans la dimension unipathique (dans cette description, l'autrice démontre une fois de plus l'influence de Scheler).

En supposant donc que l'autre est immédiatement un autre ouvert à la rencontre, et que cette rencontre, caractérisée par différents niveaux, permet une compréhension empathique immédiate et préréflexive, peut-on soutenir que cela suffit à faire de l'empathie le fondement de la moralité ? En d'autres termes, être empathique signifie-t-il vraiment être des sujets capables d'agir moralement?

Dans le dernier chapitre, Donise répond à cette question, nous montrant que la réponse n'est guère si évidente. La plupart des théories contemporaines - en premier lieu celle de Baron-Cohen - associent la cruauté à l'absence d'empathie. Il ne faut cependant pas oublier que l'autrice souligne l'existence de ce que Lipps appelle "l'empathie négative ", désignant chez lui ce sentiment semblable à un processus mimétique qui met en cause le sujet sentant, déclenchant, par exemple devant un sourire moqueur, une réaction adverse. En d'autres termes, si l'empathie désigne une façon de ressentir le monde, dont le plus haut niveau est la sympathie, c'est-à-dire la capacité à accueillir l'autre et ses vécus, cela ne signifie pas que les personnes cruelles n'en sont pas dotées. Au contraire, l'homme cruel ressent parfaitement les expériences des autres ! Scheler nous donne quelques exemples : celui qu'il appelle 1'« insensible » 
(par exemple, une personne souffrant d'une pathologie comme l'autisme ou la schizophrénie); le «brutal» (capable de ressentir mais ne porte aucun intérêt pour l'autre) et le « cruel » (qui est non seulement capable de ressentir, mais qui prend plaisir à la souffrance des autres). Dans ce dernier cas, la capacité d'empathie est donc connotée dans un sens négatif. D'autre part, la sympathie est aveugle aux valeurs, et les actions sont éthiques ou non indépendamment de celle-ci. Une fois que l'on a ressenti les expériences et les émotions des autres, il est donc de la responsabilité du sujet d'agir de manière éthique ou non. L'empathie devient donc un outil nécessaire mais non suffisant pour l'action morale, elle peut l'activer, la motiver, nous rapprocher du monde environnant et d'autrui, mais elle ne suffit pas à définir l'agent comme éthique. L'autrice relie sa thèse à des scénarios très actuels, tels que le harcèlement, le racisme (en particulier la question des migrants), l'homophobie, en nous montrant comment l'empathie elle-même est conditionnée par des éléments comme la similarité, la contiguité, la causalité.

Le lecteur dispose d'un outil important : la connaissance de la centralité mais aussi des limites (épistémologiques et morales) de la vie émotionnelle, et la capacité de reconnaître la stratification ainsi que la complexité de la conscience dans la diversité de ses nuances (de la psychopathologie aux dilemmes éthiques auxquels nous sommes confrontés chaque jour). Théorie et praxis se conjuguent harmonieusement, dans un texte grâce auquel, enfin, les émotions sortent de la dimension ineffable dans laquelle elles ont souvent été reléguées, et nous montrent la beauté de la fragilité humaine, mais aussi la force dont elles disposent pour nous permettre d'entrer dans le monde.

Valeria Bizzari

Katholieke Universiteit Leuven, Husserl Archives

Tudi Gozé, Expérience de la rencontre schizophrénique. De la bizarrerie de contact, Paris, Hermann, Phénoménologie clinique, 2020, 254 pages. ISBN : 9791037005045. Prix : $25 €$.

Sobrement intitulé Expérience de la rencontre schizophrénique, l'essai de Tudi Gozé s'impose, au fur et à mesure de sa lecture, comme une nécessité pour le clinicien intervenant dans le champ des psychoses schizophréniques. Non pas parce qu'il s'offrirait comme un guide de balisage rassurant et à usage pratique lors de la rencontre avec "l'objet schizophrène" tel que décrit par la nosographie psychiatrique dominante (qui hérite de l'ambition classificatoire 
et scientifique des Traités de psychiatrie kraepeliniens). Mais parce qu'il le plonge au plus près et au-dedans de ce qui cliniquement s'offre comme une expérience de l'écart, de l'étrangeté ou du bizarre, que l'on nomme depuis longtemps et communément « folie », et depuis un peu plus d'un siècle seulement avec Bleuler, « schizophrénie ».

Car l'ambition de l'auteur n'est précisément pas de réaliser un ouvrage de psychopathologie traitant de et portant sur la pathologie du psychologique. Il s'agit au contraire d'interroger et d'explorer à partir de la rencontre clinique ce qui se saisit, ce qui se donne à connaitre comme altérité, comme étrangeté, comme bizarrerie dans l'expérience de la folie. Il s'agit de dévoiler ce que le clinicien pourrait en tirer comme savoir, comme connaissance, depuis ce lieu d'expérience où surgit notamment un phénomène que la science naturaliste, dans son activité classificatoire inlassable, range dans la catégorie des phénomènes "pathologiques" : la bizarrerie de contact.

Celle-ci désignera ce que l'auteur soumettra à l'examen afin de tenter de répondre à une question plus fondamentale: Peut-on rendre intelligible le bizarre de l'expérience de la folie depuis notre point de vue de clinicien sans « écraser » et réduire le vécu du patient à une expérience fausse ou erronée ? Autrement dit, comment penser l'expérience d'autrui et l'expérience de la folie en les extirpant de cette manière très occidentale et moderne consistant à saisir la folie à travers une perspective normative et naturaliste, c'est-à-dire comme une rupture de l'état de santé, et localisée dans l'intériorité psychique se manifestant par la déraison et les aberrations perceptives ? L'auteur s'interroge sur les conditions de possibilités d'une psychopathologie respectueuse de la perspective d'autrui, délivrée des catégories, et reposant sur l'expérience. Il s'agit du projet le plus fondamental de l'ouvrage.

L'expérience de la bizarrerie de contact se présente à la fois comme une expérience radicale de l'altérité et à la fois comme le paradigme de l'expérience psychiatrique venant cristalliser de manière exemplaire l'ambiguïté des questions qui précèdent. En effet, la bizarrerie de contact signe, au niveau de la rencontre du clinicien avec le patient, une première « certitude » quant à la présence d'une forme pathologique de type schizophrénique, pour laquelle il n'existe pas de signe pathognomonique majeur ou d'explication biologique qui rendrait compte de l'entièreté du tableau clinique. Elle possède par ailleurs ce double caractère d'évidence et d'inintelligibilité, ce qui en fait le point de départ idoine de cette enquête psychopathologique, aux contours philosophiques, et que l'auteur se propose de mener afin de démontrer la nécessité d'une refonte de l'idée de compréhension pour l'étude des maladies dites mentales. Voilà pour le point de départ. 
Dans un premier temps, Tudi Gozé constitue une méthodologie originale centrée sur la précision et l'éclairage conceptuel de l'ensemble des éléments rentrant en jeu dans la rencontre schizophrénique. La première partie de l'ouvrage consiste ainsi, dans une perspective de psychopathologie fondamentale, en la mise en place des conditions nécessaires à la compréhension de la bizarrerie de contact. Sont ainsi d'abord explorés, avec Rümke et Minkowski, les concepts de Praecox Gefühl et d'autisme schizophrénique livrant au clinicien l'expérience d'une forme particulière et singulière, trace fondamentale de la présence schizophrénique. Vient ensuite l'exploration de l'affectivité comme capacité du clinicien à être affecté par la présence de l'autre et à en extraire une connaissance. C'est là un premier temps fort du travail que l'auteur poursuivra par l'analyse des apports de l'anthropo-phénoménologie d'Erwin Straus et la mise en évidence du sentir pathique comme mode d'appréhension de la forme du rapport sujet-monde et comme possibilité de «connaissance » de l'espace propre et humanisé du sujet sentant.

Dans la seconde partie, Gozé étudie la manière dont le corps en tant que chair, élément nécessaire de la rencontre inter-humaine, se constitue dans la dynamique relationnelle. Il s'appuie sur les apports de la philosophie de Merleau-Ponty, avant d'analyser avec Richir les rapports entre corporéité, affectivité et sentir à travers les concepts d'Aussenleiblichkeit et d'Innenleiblichkeit s'offrant dans le contact. Ceci marque le second temps fort de son enquête. L'éclaircissement conceptuel du pôle humain de la rencontre accompli, l'auteur analyse la figure d'Antonin Artaud et saisit le visage comme limite et comme lieu privilégié du chiasme des corporéités, puis se concentre sur l'informe envisagé comme renversement de la structure ontologique du contact par rupture de la dynamique réversible du contact touchant-touché. L'auteur en arrive alors à ce qu'il nomme théorie hallucinatoire de l'informe, ultime tentative de survie face à la menace de désintégration du schéma corporel. Cette analyse rigoureuse, rehaussée par un exemple clinique puisé dans la pratique de l'auteur, et constituant le troisième moment fort de sa recherche, permet de nous faire comprendre le drame infini de la schizophrénie, à savoir l'apparition d'une faille (même minime) dans la prévisibilité du contact pouvant faire basculer cette assurance d'un schéma corporel intégré sécurisant. Ce qui lui permet, en guise de conclusion, d'avancer l'hypothèse que la schizophrénie n'est plus tant à considérer comme une maladie du psychique mais de la corporéité. Le sujet schizophrène se retrouvant sans intériorité, la fermeture du contact laissant le sujet à vif, sans bordure pour être en mesure de résister à l'invasion de l'extérieur qui sera dès lors vécu comme étranger et inhabituel.

Voici donc ce que nous propose Tudi Gozé au terme de ce parcours mené aux frontières de la psychiatrie clinique et de la phénoménologie : un 
renversement salutaire de perspectives. Je dis « salutaire » parce que depuis la naissance au début du $19^{\mathrm{e}}$ siècle du mouvement aliéniste, tant en France qu'en Allemagne, le mythe de la lésion causale à titre d'explication exhaustive de la folie habite la psychiatrie. Cette idée, partie du principe de l'animal-machine cartésien, s'est vue raffermie au fur et à mesure des poussées de la rationalité scientifique naturaliste au sein du savoir médico-psychiatrique. Ainsi, la défaite des thèses vitalistes au profit des thèses mécanicistes dans l'explication du vivant, avec notamment la découverte de la structure de l'ADN en 1953, a définitivement assis l'idée que l'organisation du vivant (le biologique) dépendrait en dernier ressort de son environnement physico-chimique. Ce positionnement radical en regard du vivant a par la suite participé à l'édification du paradigme de la biologie cellulaire qui organise, au sein du biologique, des niveaux de hiérarchisation conçus comme autant de lieux d'élucidation de ses mécanismes de fonctionnement. Une telle conception du vivant s'est montrée d'une grande efficacité quant aux progrès de la science biologique, et celle-ci n'a eu de cesse d'étendre sa force explicative. Tant en intensivité, puisque des niveaux d'explication toujours plus profonds sont mobilisés, qu'en extensivité puisque de nouveaux territoires sont régulièrement annexés.

Il en va par exemple ainsi des maladies mentales. Le projet mécaniciste a voulu résoudre leur mystère par l'élucidation du (dys)fonctionnement cérébral. Cette conception du mental, déjà présente au début du $19^{\mathrm{e}}$ siècle parmi certains aliénistes puis soutenue par le modèle anatomoclinique kraepelinien, a conduit la psychiatrie à une position de plus en plus réificatrice des pathologies mentales. Ainsi, tant la sémiologie que la nosographie psychiatrique dominante actuelle sont organisées à partir et autour de signes cliniques conçus comme autant d'objets naturels dont il s'agirait d'attester la présence ou l'absence par un regard centripète depuis le lieu neutre et extérieur de l'observation. Face à une telle conception de la maladie mentale et de la psychiatrie, le livre de Tudi Gozé fait donc l'effet d'un premier renversement bouleversant mais nécessaire, sortant le clinicien de ses sentiers battus pour le mener dans l'espace de la rencontre, l'espace du chiasme des chairs et des regards où la logique de l'explication (vaine en ce lieu) s'efface au bénéfice de celle, toujours centrifuge, de la compréhension.

Le deuxième renversement majeur consiste à faire de la schizophrénie non plus le paradigme des maladies dites stricto sensu du psychique, mais bien plutôt une maladie de la corporéité. Il propose par-là de réorienter l'attention clinique autour de l'expression des vécus corporels depuis une perspective en première personne. Car ce n'est plus tant la présence d'hallucinations et d'idées délirantes qui signent l'atteinte schizophrénique mais bien, dans la ren- 
contre de chair à chair, l'inscription de l'ineffable et bizarre expérience de l'informe depuis le corps du malade jusqu'au corps du clinicien. L'intérêt clinique d'un tel positionnement est qu'il permet et rend légitime l'exhumation de tout un savoir théorico-clinique tombé progressivement en désuétude au fur et à mesure que les théories mécanicistes, accompagnées de celles de l'evidence base medicine, gagnaient le champ psychiatrique. Je pense ici aux travaux d'Abely ou encore à ceux de Gisela Pankow pour lesquels le travail de Tudi Gozé offre de nouveaux prolongements.

Le troisième renversement majeur est que cet ouvrage nous invite à repenser et à réorienter fondamentalement notre cadre thérapeutique ainsi que nos propositions de soins à l'endroit des malades schizophrènes du côté des soins dits primaires (au sens winnicottien du terme), plutôt que selon ce modèle causaliste naturaliste ne comprenant le symptôme que comme le signe d'un défaut à régler par la thérapeutique (notamment neuroleptique). La conception du cadre tel que pensé par Christophe Chaperot (Réflexions sur le cadre thérapeutique et l'institution : médiatisation et caractère partiel. dans Évolution psychiatrique, 2003) nous semble ainsi parfaitement adaptée à ce type de projet. Ce dernier conçoit le cadre thérapeutique comme ayant pour fonction de maintenir les conditions de possibilité d'une rencontre au sens clinique et psychothérapeutique du terme. Pour ce faire, il propose de déployer celui-ci dans deux perspectives différentes. La première, générale, viserait la dimension du cadre pensé comme système de balisage général contenant l'ensemble des règles institutionnelles faisant valeur pour tous et s'offrant comme garantie du maintien de l'espace de la rencontre. La seconde, plus singulière, s'entendrait comme ensemble de mesures thérapeutiques conscientes et inconscientes, élaborées, et adressées en propre au sujet. Chaperot pense ce cadre singulier comme constitué de deux éléments. Ce qu'il nomme l'hypercadre, et que nous dénommerions cadre interne, se définit comme l'élaboration par le sujet de son propre système de balisage. Et l'épicadre, ou cadre externe, désigne un ensemble de mesures thérapeutiques conscientes et inconscientes, élaborées, et adressées en propre au sujet. Cet épicadre veillera à ne pas fournir toutes les réponses aux questions du sujet, ne cherchera pas à résoudre ses interrogations par une réponse institutionnelle, ne s'attèlera pas à imposer l'idéal imaginaire du bon soin prodigué par la figure du médecin ou du clinicien savant. Au contraire, il promouvra le manque, la lacune afin que naisse cette tension nécessaire à l'intersubjectivation des corps, condition fondamentale à l'émergence de l'espace de la rencontre qui s'instaure précisément aux points d'intersection des deux sous cadres. Aussi, les réflexions de Tudi Gozé nous apportent le matériau et la possibilité de penser un épicadre rassurant, solide 
et suffisamment bon, façonné autour des enjeux cliniques de la chair (notamment de l'Innenleiblichkeit). Il permet d'offrir au malade un point d'appui certes branlant, mais suffisant pour faire office de soutien afin de résister à la menace de l'informe. Il s'agit d'un épicadre qui accepterait le maintien d'un rapport, d'un contact dynamique avec l'hypercadre du sujet.

Il nous reste à remercier Tudi Gozé pour les chemins qu'il a ouverts avec force et rigueur devant nous, nous permettant de nous promener dans cet univers si particulier auquel appartient la clinique psychiatrique, habitée dorénavant d'une pensée plus libérée des conceptions réificatrices des maladies mentales. C'est aussi et surtout par cela qu'au-delà de tout ce qu'il contient de richesse pour le clinicien, cet ouvrage est une parfaite réussite.

Johan Kalonji

Médecin psychiatre, Université catholique de Louvain, SSSP prison de

Saint-Gilles

Silvia Federici, Par-delà les frontières du corps, Paris, Éditions Divergences, 2020, 152 pages. ISBN : 979-10-97088-24-8. Prix : $15 €$.

Par-delà les frontières du corps : la phénoménologie sartrienne, un héritage possible pour le féminisme matérialiste?

Par-delà les frontières du corps ouvre une perspective nouvelle sur les questions les plus brûlantes du champ féministe actuel, tant dans ses dimensions scientifiques que militantes. Silvia Federici, en réactualisant des généalogies philosophiques, des concepts issus de la théorie politique marxiste et en tordant les usages usuels de ceux-ci, opère une série de décalages et de prises de position singulières au sein du féminisme et des études de genre, notamment en installant un rapport critique voire conflictuel avec les théories de la performance ou de la performativité ${ }^{1}$. La portée de cet ouvrage ne se restreint pas aux champs qu'il semble investiguer directement, à savoir le féminisme et le marxisme ; au contraire, que ce soit en filigrane ou explicitement, il interroge, remanie, discute et hérite d'une certaine pensée phénoménologique du corps. Notre lecture consiste à reprendre les thèses principales que présente l'autrice à partir de ces renvois discrets, à la lumière de ce qu'on peut qualifier de pensée phénoménologique du corps, et d'en montrer l'opérativité conceptuelle au sein de ce qui s'impose, avant tout, comme relevant du féminisme matérialiste. 
La manière dont Federici pose l'enjeu d'une pensée philosophique du corps à partir d'une gestualité technique qui en repousse les frontières rompt, de manière parfois déroutante ou allusive, avec une série de repositionnements stratégiques qui ont marqué le champ féministe depuis les années 1990. Nous pensons notamment à la façon dont Federici s'attaque à une série de travaux issus d'une mouvance post-structuraliste (qui semble couvrir, selon l'autrice, aussi bien les travaux de Foucault que ceux de Butler ou de Donna Haraway) qui ont opéré des ruptures au sein de la lutte et de la théorie féministes. Federici reconfigure en réalité une généalogie du concept de corps au croisement de deux héritages ; elle articule la signification et les politiques du corps véhiculées par le mouvement féministe des années septante auquel elle appartient avec un héritage aux accents phénoménologiques et existentialistes (principalement issu de Sartre et de Beauvoir). Cet héritage hybride lui permet de penser une série d'expériences limites propres au contexte économique, technique et politique dans lequel nous évoluons : principalement les formes d'expropriation et d'exploitation des corps racisés qui structurent le marché des nouvelles technologies reproductives ainsi que la dépendance au système médical instituée par les pratiques de chirurgie de transformation. Poser les enjeux de ces nouveaux types d'intervention sur les corps génère une intrication philosophique entre féminisme, technique scientifique et politique.

C'est à l'aune de ces nouvelles urgences et en poursuivant la ligne d'un travail entamé il y a une trentaine d'années ${ }^{2}$ que Silvia Federici produit une réflexion inédite pour son œuvre ${ }^{3}$. Elle fait coexister une focale d'analyse tournée vers le passé et une autre résolument décidée à penser ce qui nous arrive, c'est-à-dire ce qui simultanément se passe au présent et s'achemine vers nous. Penser les techniques actuelles qui s'appliquent aux corps, développer un point de vue sur leurs conséquences politiques futures et reconstruire l'histoire du système économique dans lequel elles s'inscrivent sont autant de gestes qui permettent à Federici de dresser un avatar des luttes possibles. Elle construit dans son ouvrage une grille d'analyse féministe et matérialiste dont la force de frappe impressionne : partant de ses analyses du cadre conjugal, des modèles sociaux familiaux (que Jules Falquet requalifie à l'occasion de sa préface, et à juste titre, d'hétéronormatifs) et de leur judiciarisation, elle poursuit son analyse par une étude de la disciplinarisation genrée effectuée conjointement par la montée du salariat et de la psychologie. Au cours de ce trajet philosophique et militant, l'autrice n'a de cesse de redéployer les impensés et les concepts marxistes liés à la question de l'exploitation et de renouveler les problèmes qu'elle tient à y associer (chirurgie esthétique et de transformation des corps, politiques de l'identité et nouvelles technologies reproductives). 
Federici se saisit de la pensée de Sartre d'une façon aussi éparse que surprenante et décisive. Il s'agit, pour nous, de voir ce que permettent les références classiquement sartriennes au sein de la réflexion de l'autrice. Pourrions-nous en tant que lectrice convertir ce qui semble être de simples notes en éléments nécessaires au développement conceptuel porté par Federici ? Pourrions-nous en densifier l'usage, c'est-à-dire faire du déploiement interne de la pensée sartrienne une ressource stratégique pour faire compter une série d'expériences-limites du corps ? La présente proposition consiste ainsi à relire l'articulation interne à l'œuvre de Sartre entre phénoménologie et pensée matérialiste et d'en faire un point à partir duquel nous pouvons saisir et rendre compte des gestes philosophiques de Federici.

L'échelle du corps sert d'opérateur à Federici pour penser les processus d'aliénation capitalistes en ce qu'ils sont permis, d'une part, par l'expropriation des capacités corporelles et reproductives, et, d'autre part, par la division sexuelle du travail. L'attention du.de la lecteur.trice relèvera sans doute les quelques références à Sartre dans le texte, principalement chevillées aux critiques que Federici adresse aux théories de la performance. Nous suggérons que les effets de résonnance entre Sartre et Federici ne se limitent pas à ces renvois explicites ; ielles mobilisent chacun.e l'héritage marxiste pour penser l'expérience de certains corps (ceux des femmes au foyer, des femmes esclaves, des femmes racisées, des mères porteuses, des personnes trans ou intersexes, des travailleuses du sexe, ou encore des ouvrières à la chaine) ; leurs façons propres de tenir côte à côte corps aliénés et philosophie marxiste s'offrent respectivement du relief. Par l'attention qu'ielles portent sur les opérations qui font de certains corps des corps structurellement opprimés, Sartre et Federici s'inscrivent dans un remaniement de la voie marxiste. Pour comprendre cette inscription qui marque simultanément un décalage, il nous semble nécessaire de revenir à certains gestes phénoménologiques, précisément parce qu'ils construisent le point de jonction entre pensée politique structurelle et expérience subjective de l'aliénation. Ce que l'itinéraire philosophique de Sartre permet de penser, c'est comment et pourquoi l'attachement au corps est possible au sein d'une philosophie matérialiste, c'est-à-dire comment l'échelle du corps traduit une multiplicité d'expériences qui ne peuvent être tues, ni s'effacer dans des concepts. Il poursuit, en déplaçant ses coordonnées initiales, le geste marxiste qui consiste à comprendre la classe comme ce par quoi l'individu se voit assigner sa position sociale et, par suite, son développement personnel ${ }^{4}$. Poursuite et remaniement que Silvia Federici semble, elle aussi, coder avec singularité et adresse. Une lecture possible de Par-delà les frontières du corps consiste à tisser différents fils avec la pensée de Sartre à partir de ces échos que l'on pourrait qualifier, à première vue, d'anecdotiques 
mais qui se révèlent, si l'on y prend garde, être de véritables appels du texte vers un réseau d'alliances possible.

L'échelle du corps ou la pluralité existentielle — l'existentialisme comme concept critique et comme outil de lutte

Par-delà les frontières du corps restitue le cadre théorique élaboré par Federici depuis Caliban et la Sorcière ${ }^{5}$, à savoir l'analyse de la transformation des corps en machines de travail comme l'un des principaux projets du capitalisme (p. 33). Les différents chapitres déclinent les rapports entre capitalisme et mécanisation des corps : "La transformation capitaliste des corps en machine (ouvrière, procréatrice, esclave), inorganique, socialement mort, est la condition de production du travail abstrait [...] indispensable à la création capitaliste de valeur » (p. 12-13). Federici s'empare de l'histoire d'une aliénation spécifique, celle qui s'exerce sur le corps des femmes dont la capacité reproductrice est captée par le capitalisme. Une des focales les plus centrales pour poser la connexion entre le procès capitaliste et les enjeux féministes est celle de la maternité et de la puissance reproductive. Par cette question, l'analyse de l'aliénation subjective est renouvelée en même temps que la compréhension de la structuration genrée des processus économiques dont le système capitaliste dépend. Le travail reproductif assigne une série de places spécifiques dans la division capitaliste du travail (p. 9) ; les corps qui occupent ces places sont quant à eux défini.es par un champ restreint de possibilités existentielles et par les violences structurelles dont ils sont victimes. La première partie configure un point d'entrée thématique présent dans l'ensemble du livre, celui des trajectoires existentielles en régime capitaliste. La captation de la puissance reproductive des femmes est l'axe principal par lequel Federici présente l'aliénation comme phénomène existentiel et politique.

Le contrôle du corps des femmes est décliné par l'autrice en termes de force de travail (rémunérée ou non), d'objet sexuel, et de machine reproductrice. Cependant, elle ne résume pas les processus d'aliénation à la captation du corps des femmes ; elle prend acte des autres types d'oppression qui pèsent sur les corps minoritaires et manifeste, par-là, la complexité des violences structurelles à l'origine de l'aliénation de certains corps et de certaines vies. Elle corrige ainsi ce qu'elle qualifie elle-même de point aveugle du mouvement féministe des années septante. Le contrôle et l'expropriation des capacités reproductives de femmes sont des opérations qui ont lieu parce que d'autres formes de contrôle et d'exploitation s'appliquent à d'autres corps, principalement ceux des femmes racisées. Alors que la capacité reproductrice de certains 
corps est chevillée au processus capitalistique en termes de ressource, l'accès à la maternité est criminalisé pour d'autres femmes. Cette imbrication des dominations structurelles a conduit à des déplacements de la violence ou à une cécité dans les milieux militants et académiques. Cette double attention de l'autrice (à son objet d'étude et à la hiérarchisation des violences qui y est attaché) révèle une volonté de rompre avec ces points d'aveuglement et de faire droit à une pluralité d'histoires : autant d'histoires que de "modalités spécifiques de mécanisation du corps » (p. 33), voilà l'exigence fixée. La multiplicité de récits n'empêche pas Federici de soutenir, à l'encontre des théories discursives/performatives, la nécessité de penser les dimensions structurelles de ce que nous pourrions qualifier de champ expérientiel du corps.

Ces possibilités d'expériences corporelles sont considérées par l'autrice aussi bien comme des pratiques ou réalités existentielles que comme des réalités politiques. L'articulation conceptuelle entre ces différents niveaux est décelable à même les expériences corporelles qu'il s'agit de penser : les vécus subjectifs témoignent de la structuration socio-politique dans lesquels ils ont lieu, ainsi que de la nature intersectionnelle des dominations sexistes, racistes et classistes qui façonnent le champ d'expérience subjective. La pluralité existentielle qui est ainsi mise en jeu ne déforce pas la nécessité d'une analyse matérialiste ; au contraire, elle en émane. Les corps dont il est question manifestent une exigence: une pensée de l'aliénation ne peut se détacher d'une compréhension du corps comme itinéraire singulier.

Dans le même temps, les problématiques posées par Federici et les généalogies qu'elle mobilise pour les traiter recomposent un positionnement singulier dans le champ féministe. Construire une pensée du corps aliéné depuis les instruments de la lutte féministe des années septante équivaut à penser les phénomènes d'aliénation de sexe et de genre à l'encontre du type d'analyses dominantes depuis les années 1990, analyses dites post-structuralistes :

Le marxisme et la plupart des philosophies du $19^{\mathrm{e}}$ siècle - en particulier l'existentialisme, qui a influencé Butler — ont attaqué l'idée d'un sujet fixe et essentiel. Nos corps sont modelés par les rapports de classe, autant que par les facteurs ethniques et les décisions existentielles que nous prenons. Ainsi, la lutte pour déstabiliser les identités assignées ne peut être séparée de la lutte pour changer les conditions sociales et historiques dans lesquelles nous vivons et surtout attaquer les hiérarchies sociales et les inégalités. (p. 55)

La lutte des années septante porte un écart avec les théories postérieures de Butler et de ses héritiers.ères : elle ne refuse pas les identités mais les compose comme un champ de bataille (p. 73), comme un lieu de lutte qu'il s'agit d'investiguer. Cette préoccupation a ceci d'essentiel pour la pensée de Federici : 
la lutte des années septante visait à dénaturaliser la notion de féminité pour porter le combat contre l'exploitation du corps des femmes; a posteriori elle révèle aussi que le combat ne peut pas être mené sans changer radicalement les conditions matérielles d'existence des femmes. L'identité n'est pas un repoussoir du féminisme mais bien une dimension de sa lutte. Le souhait exprimé par Federici est que la séquence des années septante (et la critique des théories post-structuralistes qu'elle véhicule en sous-main) puisse elle aussi faire héritage et rendre puissantes les luttes pour l'autodétermination, notamment celles portées aujourd'hui par les mouvements queer et trans : il n'y a pas de lutte collective et de victoire possibles autour des conditions des minorités sans faire compter le caractère profondément labile et historique des identités avec lesquelles nous existons, nous négocions et nous luttons dans le champ politique et social.

Federici interroge donc toujours la condition des femmes; et elle le fait dans ce qu'elle diagnostique comme une "crise de la reproduction aujourd'hui ». La vie des femmes en ce qu'elle est «brutale, courte et pénible» (p. 59) nous révèle, de manière criante, l'état des possibilités d'existence de notre présent. La fragilisation et la précarisation observables dans la pluralité existentielle doivent se penser aux côtés de la destruction de la nature, de nos attachements, et de nos liens aux autres vivants. Par-là, Federici défend l'étendue de la lutte féministe à faire ; une lutte qui ne saurait s'opérer si elle ne prend pas pour objet les conditions matérielles d'existence et ne s'allie pas intrinsèquement aux combats antiracistes, anticarcéraux, écologistes, ainsi qu'à ceux liés à la situation des enfants.

Institutions et catégories sociales : qu'indiquent les corps des agencements socio-politiques?

Cette lutte que Federici mène pour le corps des femmes s'articule à d'autres luttes qui font apparaitre la dimension stratégique de l'héritage mobilisé par Federici. Donner ce cadre de référence à la lutte et à la pensée féministe conduit l'autrice à rentrer plus frontalement dans la critique qu'elle adresse au concept de performance dont le risque est de « cacher des éléments structuraux du système capitaliste mais aussi [1'histoire des] les luttes » (p. 72). Ce concept ne permet pas de saisir que l'envergure du combat que ces minorités doivent porter : il est nécessaire « non seulement [de produire] une transformation de notre vision individuelle et collective du genre mais surtout des institutions qui le perpétuent, à commencer par la division sexuelle du travail et les hiérarchies sociales fondées sur la dévaluation du travail reproductif» (p. 71). Federici 
insiste sur la nécessité de penser et de mener ces révolutions à partir du lieu où l'expérience de l'exploitation se donne. L'expérience des corps est plurielle ; pourtant, le capitalisme, en tant que système sexiste, raciste, classiste et hétéronormatif, exploite et discipline cette multiplicité. Le corps est donc un « territoire à défendre » (p. 76), il est un lieu de possibilités politiques et de lutte ; et ce, parce qu'il constitue une échelle d'expérience où sont appréhendables les effets matériels des assignations à des signifiants dont le contenu est socialement construit et l'épreuve des conditions matérielles d'existence.

Performer d'autres usages du corps et refuser les catégorisations sociales du genre ne semblent pas constituer, à eux seuls, les axes ou les modes d'action d'une lutte possible. Federici souligne sa méfiance à l'égard des prétentions des transformations physiques à porter de nouvelles possibilités de vie. Une révolution qui voudrait défaire le genre ne peut avoir lieu dans « un monde qui n'a pas changé » (p. 60). Les possibilités d'existence ne sont pas constitutivement individuelles (risque qu'elle voit comme intrinsèque aux théories de la performance) mais bien une réalité sociale et politique ; la lutte contre l'oppression structurelle des corps est nécessaire pour inventer de nouvelles possibilités de vie. "Changer nos corps, reprendre le contrôle de notre sexualité et de notre capacité de reproduction signifie changer nos conditions matérielles d'existence » (p. 58). En se réappropriant leurs corps, les femmes, les personnes trans, les personnes intersexes, agissent contre les structures de l'exploitation capitaliste et participent à l'élaboration collective d'un autre monde possible.

À ce titre, Federici prend acte de la modification impressionnante qu'entrainent les nouvelles bio-technologies pour la question du corps. La chirurgie esthétique, utilisée dans le cadre d'opérations de changement de sexe entre autres, manifeste le rapport de dépendance entre transformation individuelle du corps et appareil médical. Federici pose alors en quelques points l'intrication de la science médicale à l'État et au capitalisme ; elle présente les processus de transformations physiques en ce qu'ils n'interrogent pas les dimensions oppressives de cette institution, les structurations sociales et le régime d'inégalité qu'elles instaurent, ainsi que les standards patriarcaux de beauté auxquels ces opérations peuvent répondre. La réflexion se poursuit au travers de la question, brûlante dans le champ féministe actuel, de la GPA. Par la structuration classiste et raciste des pratiques de GPA, cette technologie de reproduction engage l'autrice à construire une triple problématisation : d'abord, elle interroge la généalogie de cette pratique avec celle de nourrice dans l'économie esclavagiste de la plantation ${ }^{6}$; ensuite, elle explicite les normes racistes qui pèsent actuellement sur la procréation ${ }^{7}$; et, enfin, elle investit à nouveaux 
frais et d'un point de vue féministe la formule de Marx selon laquelle le travailleur, vendant femme et enfant(s), devient marchand d'esclaves ${ }^{8}$. Le corps est machiné et capitalisé en même temps qu'il est sexualisé, racisé, classisé. La prolifération de techniques relatives à la maternité ou au genre ne doit pas nous tromper ; elle ne fait pas état d'un élargissement du spectre d'expériences subjectives possibles.

Ces deux exemples éclairent la position singulière de Federici. La pensée féministe qu'elle défend repose sur des opérations stratégiques collectives (même si elles impliquent de se regrouper derrière des catégories qui, paradoxalement, sont aussi l'objet de la lutte) et sur la réappropriation totale des expériences du corps vis-à-vis des institutions qui nourrissent l'économie capitaliste. L'horizon de la lutte, quant à lui, est clair : il doit consister à créer un cadre nouveau d'expériences subjectives et collectives. Cette révolution des possibilités existentielles implique de rompre avec la généalogie des différents systèmes d'oppression : le capitalisme, fruit des régimes esclavagistes et coloniaux, ordonne le registre d'expériences que certains corps peuvent vivre ou non parce qu'il crée, à mesure que son ordre se déploie, des oppressions de sexe, de classe, et de race; il ne peut que constituer, à ce titre, un système politique dans lequel les possibilités de certains corps dépendent de la réduction du spectre d'expériences possibles et de l'augmentation des violences pour certains autres. Autrement dit, les structures économiques et sociales du capitalisme procèdent à une hiérarchisation des possibilités d'existence. Le féminisme matérialiste semble éclairer, par le biais du cas des minorités sexuelles, cette hiérarchisation de la valeur attribuée aux corps.

Machinisation du corps et corps-territoire: pour une phénoménologie de l'aliénation et de la liberté

Silvia Federici explicite l'enjeu d'un retour à la question du corps sans équivoque : « revenir sur la manière dont le capitalisme a fait du corps une force de travail permet de relire nos pathologies collectives et individuelles et d'y chercher de nouveaux paradigmes anthropologiques » (p. 102). La question du corps place les travaux de Federici au croisement de la clinique (dont les dimensions sont subjectives et sociales) et de la politique. La perspective sur le corps défendue par l'autrice implique de penser aussi bien les processus d'aliénation que ceux de libération, de penser aussi bien les configurations dans lesquelles les corps sont opprimés que l'éclosion de luttes collectives. La crise que connait le capitalisme depuis les années 1960 fonctionne pour Silvia Federici comme un rappel auquel nous devons tenir : les corps ne sont jamais 
exclusivement convertis en machine, ils restent par là des forces de lutte impossibles à maitriser. Les luttes sexuelles, sociales et structurelles ont bien pour objet et pour effet de « redéfinir le corps pour le rendre autonome de son fonctionnement en tant que force de travail » (p. 111). À cela, le système économique semble opposer la précarisation et la peur du lendemain, moyen que l'autrice englobe sous le terme de terreur (p. 110-112) et qu'elle analyse comme étant le procédé de contrôle des corps le plus actuel dont dispose le capitalisme. Le problème de la machinisation et celui de l'émergence des luttes témoignent des deux faces qui composent la question du corps : d'une part, il est l'échelle de pensée qui permet de conceptualiser la pluralité des expériences de la violence et, d'autre part, il est l'échelle qui permet de penser la dimension politique de chaque champ expérientiel et la possibilité qu'il abrite de constituer un foyer de résistance aux agencements dominants.

Federici insiste, à la clôture de son ouvrage, sur la part de ce qui, dans les corps, résiste, c'est-à-dire sur l'exercice créatif de ses mouvements, de ses capacités physiques (p. 131). Par la danse, le corps semble explorer une facette de la résistance, explorer ce qui, de lui, échappe purement et simplement à la machine. Le corps et sa danse sont le lieu d'une puissance inexorable dont on peut penser qu'ils nous connectent à la possibilité même de lutter. Federici rend perméables deux voies d'analyse : une analyse structurelle des conditions d'existence et une attention aux corps tant dans leur expérience de l'aliénation que dans celle de la lutte. Ce faisant, et comme Jules Falquet l'indique dans sa préface, Par-delà les frontières $d u$ corps construit une position décalée, un vrai pas de côté dans le champ féministe (p. 10). Sartre a frayé une voie à la croisée d'une conception phénoménologique du corps et d'une pensée matérialiste de l'oppression. Il ne serait pas opportun de comparer les pensées de Sartre et Federici, ni de faire comme si les chemins qu'ielles avaient tracés étaient similaires. Cependant, opérer des rapprochements entre leurs façons de faire pénétrer l'échelle du singulier et celle du structurel n'est pas anodin. Il s'agit d'aborder ce qui de la pensée de Sartre peut servir de généalogie stratégique pour la pensée féministe.

Sartre, la configuration d'un problème matérialiste : au sujet des impasses existentielles

Dans la première partie de son ouvrage, Federici poursuit le projet de Caliban et la Sorcière en montrant que la mécanisation du corps est aussi bien un effet qu'une condition de possibilité du capitalisme. Cette mécanisation ou machinisation du corps repose sur un système ciblé d'oppressions : dominations 
sexuelles, raciales, et de classe. Afin de relier la nature structurelle de ces dominations et leurs conséquences existentielles, l'autrice mobilise une analyse des études tayloristes comme outil scientifique qui a permis la mécanisation du travail à la chaine. Elle qualifie à l'aide d'une expression de Huis $\mathrm{Clos}^{9}$ cette mécanisation, la transformation du corps qu'elle implique et le type d'expérience qu'elle produit. L'automatisme et la mécanisation du corps généré.es par le procédé tayloriste de fragmentation et d'autonomisation des tâches produisent des types d'existence que Sartre (et Federici qui le reprend) qualifie(nt) de vies « sans issues » (p. 35). Les vies sans issues désignent dans la pièce de Sartre, écrite en 1943, le caractère irrémédiable des choix existentiels posés au cours d'une vie. La pièce met en scène trois personnages qui, au jour de leur mort, sont en situation de rendre compte de leur existence. Leurs vies sont passées au crible et sont définies par l'ensemble des actes qu'ielles ont posés ; le dispositif de la scène (être rassemblés tous.tes les trois) fonctionne comme une instance de jugement. Par cette pièce, Sartre pose deux problèmes qui vont traverser la première partie de son œuvre : la connaissance de soi et la constitution de soi. Il y articule d'emblée la notion d'autrui dont il fera un élément central pour penser ces deux problèmes de nature phénoménologique.

La réalité matérielle (mécanisation du travail) que Federici qualifie avec l'expression de Huis Clos fait résonner, de façon surprenante, le travail entrepris des années plus tard par l'auteur dans la Critique de la Raison dialectique $^{10}$; plus précisément, l'analyse qu'il déploie au sujet d'une ouvrière à la chaine. Que peut dire cette autre référence sartrienne et vers quoi fait-elle signe?

Dans la Critique, Sartre produit une analyse de la classe sociale comme " champ de possibilités rigoureusement limité ${ }^{11}$. Il développe son analyse par une série d'exemples, dont l'un est particulièrement frappant : la description des gestes, des pensées, des désirs et des possibilités existentielles d'une ouvrière à la chaine. Pour développer son analyse matérialiste et historique du concept d'aliénation, Sartre reprend et amplifie un texte de Lanzmann au sujet d'une ouvrière dans une fabrique de shampooing Dop ${ }^{12}$. Ce dont il est question dans la description que fait Sartre de cette ouvrière, c'est non seulement de tout ce qui lui est assigné par la classe à laquelle elle appartient, mais ce sont également les exigences pratico-inertes des lieux et des objets auxquels elle est confrontée en tant qu'ouvrière, en tant qu'être-de-classe, et qui vont jusqu'à configurer et réintégrer au procès capitaliste ses échappatoires dont on peinera à dire, dans un premier temps, qu'elles lui sont « propres ». 
En vain, se réfugierait-elle dans l'intimité « la plus privée», ce prétendu recours la trahirait aussitôt et se transformerait en un pur et simple mode de réalisation subjective de l'objectivité. Aux premiers temps des machines semiautomatiques, des enquêtes ont montré que les ouvrières spécialisées se laissaient aller, en travaillant à une rêverie d'ordre sexuel, elles se rappelaient la chambre, le lit, la nuit, tout ce qui ne concerne que la personne dans la solitude du couple fermé sur soi. Mais c'est la machine en elle qui rêvait de caresses : le genre d'attention requis par leur travail ne leur permettait, en effet, ni la distraction (penser à autre chose) ni l'application totale de l'esprit (la pensée retarde ici le mouvement); [...] l'ouvrière pense à l'abandon sexuel, parce que la machine requiert qu'elle vive sa vie consciente en passivité pour garder une vigilance souple et préventive sans jamais se mobiliser dans la pensée active. [...] La vérité, c'est que l'ouvrière en croyant s'évader trouve un biais pour se faire ce qu'elle est [...]. Ainsi la plus grande intériorité devient un moyen de se réaliser comme une extériorité totale. ${ }^{13}$

L'ouvrière, par ses gestes et ses rêveries, est tout entière rivée à la machine ; elle est machine ou plutôt elle se fait être machine. La mécanisation du corps qu' exigent la machine industrielle et la structuration du travail à la chaine fait d'elle une pure force de travail, une ressource matérielle. L'appropriation de son corps en force de travail est le point qui configure son champ de possible. C'est bien son être-de-classe, c'est-à-dire la position que son corps est destiné à occuper dans les processus de production capitaliste et les tâches qui lui sont assignées en raison de la division économique et sociale du travail, qui constitue l'ensemble de son existence. L'ouvrière est « définie non seulement par le type de rêverie intérieure que la machine l'oblige à avoir, mais par le salaire, par les maladies, par la vie, par le nombre d'enfants qu'elle peut avoir $[\ldots] »^{14}$.

On s'étonnera dès lors peut-être que Federici mobilise ainsi l'expression de Huis Clos, ouvrage étranger aux questions de l'aliénation générée par le travail industriel, afin de qualifier une expérience dont Sartre fait, ailleurs et dans une discussion explicite avec le marxisme, une analyse serrée et détaillée. L'élément sartrien que reprend Federici est de l'ordre du motif : il s'agit bien de penser les enjeux philosophiques des « vies sans issues », c'est-à-dire des vies absolument «prévisibles » (p. 35). À la faveur d'une note, Federici situe brièvement son intérêt pour la formule en question : l'enjeu de Huis Clos auquel elle est sensible est celui de «l'auto-emprisonnement» (p. 145). De retour à son propre texte, Federici déplace l'enjeu de l'auto-emprisonnement du champ phénoménologique, qui renvoyait chez Sartre aux problèmes de la subjectivation et de l'intersubjectivité, vers le champ structurel et politique. Les vies sans issues désignent, par ce déplacement, des vies cadenassées par les contraintes socio-économiques, des vies dans lesquelles «le capitalisme a 
traité nos corps comme des machines de travail parce qu'il est le système social qui a systématiquement fait du travail humain le principe d'accumulation de la richesse, le système qui a le plus besoin de maximiser son exploitation » (p. 34). Par-là, Federici active un lien solide entre les premiers textes de Sartre, lecteur de Husserl et Heidegger, occupé à saisir la nature de la relation entre conscience et situation et à construire une philosophie existentialiste, et la pensée matérialiste de l'aliénation qu'il produit à la fin de son œuvre.

Cette note configure un premier point d'attention que partagent Sartre et Federici portant sur l'expérience subjective de l'aliénation. Ces vies sans issues témoignent d'une structuration de l'existence qui est telle que nos corps sont pris dans des champs de possibilité socialement et historiquement constitués. Le travail de Federici consiste à retracer l'historicité de ces champs, la portée et la nature des déterminations qu'ils impliquent, les corps sur lesquels ils s'appliquent. La pensée phénoménologique de Sartre, depuis La Transcendance de l'Ego ${ }^{15}$, permet de fonder la nature de l'expérience du corps tel qu'il est toujours pris dans une situation (qui contient son champ de possibilités et d'impossibilités). L'existentialisme et la structuration de l'expérience dont il dépend déterminent la question de l'aliénation ; l'aliénation ne se pense pas, chez Sartre, uniquement dans des termes structurels mais dépend de la nature du rapport entre le corps, la conscience et la situation d'incarnation. Parce que tout corps est toujours en situation, il importe de produire l'analyse matérialiste des configurations sociales et économiques qui pèsent sur les corps jetésdans-le-monde ${ }^{16}$. Raphaël Gély a problématisé le lien conceptuel entre les concepts sartriens de corps, de conscience et de situation. Dans son ouvrage qu'il qualifie lui-même d'exercice phénoménologique à partir de Sartre, il déploie une des grandes lignes de la pensée sartrienne : qu'est-ce que peut un corps en situation? Comment les composantes sociales d'une situation affectent-elles les possibilités existentielles d'un corps? :

C'est la vulnérabilité intrinsèque de l'ouverture de la conscience au monde qui la rend si profondément réceptive à l'organisation sociale de son agir, aux façons, socialement structurées, d'organiser son agir et la façon même dont elle est censée le théâtraliser. [...] C'est dire que la dimension singulière et la dimension sociale de l'agir passe par le corps, par la façon dont il est susceptible en situation d'être imaginarisé. ${ }^{17}$

Ce sont bien les pouvoirs de la conscience, décrits par la phénoménologie sartrienne (notamment l'émotion et l'imagination), qui assument et répondent à la structuration d'une situation au sein de laquelle des corps sont exposés : 
L'émotion chez Sartre est une conscience, confrontée à un monde difficile, qui se fait magique, non pas en cherchant l'évasion, mais en mobilisant cela du monde qui reste à sa disposition, son propre corps, en explorant l'efficacité symbolique des techniques qui restent à sa disposition, ses techniques corporelles, capables de mettre en question d'un coup les moyens, les médiations et les rapports qui organisent le monde, en en montrant tout à la fois la précarité et les limites. ${ }^{18}$

La phénoménologie sartrienne permet de jouer les deux facettes de l'expérience subjective l'une avec l'autre, plutôt que de produire une pensée qui produirait une compréhension du concept de corps sur le dos d'une inattention aux conditions d'existence. En ce sens, le socle phénoménologique de la pensée sartrienne pose la question des conditions matérielles de l'expérience, des conditions dans lesquelles un corps et une conscience peuvent exercer un rapport créatif à leur situation de vie. Le projet de la Critique se construit des années plus tard, dernier tournant de l'œuvre sartrienne, et consiste toujours à penser l'homme en situation. Pourtant un autre angle s'impose : la notion de situation est traitée dans ses dimensions historiques, économiques et sociales. Cela implique de décrire l'expérience de l'aliénation à l'échelle du corps (de chaque corps) comme déploiement d'une subjectivation dans les dispositifs sociaux qui configurent ses possibilités. L'échelle du corps, comprise depuis l'ancrage phénoménologique dont dépendent les concepts classiquement sartriens de situation et de conscience, s'impose comme ressort philosophique : elle permet de saisir l'ampleur des impacts sociaux, historiques et matériels et forme, à partir de là, le socle d'une véritable pensée matérialiste.

Héritage(s) en tension : l'existentialisme, révélateur d'impasses théoriques?

La seconde apparition de Sartre dans l'ouvrage de Federici est articulée à la fameuse citation de Beauvoir: «On ne naît pas femme, on le devient $»^{19}$. Sartre et Beauvoir font surgir les enjeux existentialistes dans un chapitre destiné à faire la critique du concept de performance ou des théories discursives du genre. Silvia Federici souligne les points de la théorie de Butler qui constituent, d'après elle, des impasses théoriques et militantes. Force est de constater, pourtant, qu'en mobilisant Sartre et Beauvoir dans son chapitre sur « Le corps, le genre et la performance » (p. 69-77), elle construit davantage une tension ou un rapport critique dans un champ de recherche qu'elle partage avec Butler. Federici fait mine d'être sourde à certaines nuances ou à certains points de la théorie de la performativité. Ce survol a une efficacité stratégique indéniable : il positionne, avec la clarté qu'offre une critique assumée, les travaux 
des deux autrices dans le champ féministe. Mais cet effet d'opposition se situe en surface ; cette hétérogénéité apparente de leurs théories est, en réalité, traversée par une série de tensions. Leurs positions respectives ne s'opposent pas terme à terme ni radicalement mais sont plutôt prises dans une négociation complexe. Les façons d'hériter des auteurs.trices de la French Theory ${ }^{20}$ manifestent une de ces tensions et poussent chaque pensée dans ses retranchements ou au-devant de ses impasses.

Federici retrace la façon dont, à partir de Beauvoir, un certain mouvement féministe, le sien, a dégagé la nécessité de combattre les sources d'exploitation des femmes. Cette lutte cherchait alors « des stratégies politiques qui transformeraient non seulement nos propres vies [la vie des femmes] mais aussi la totalité sociale » (p. 69). La force de ce trajet est racontée au revers d'un autre itinéraire, lui aussi hérité de Beauvoir, celui des théories de la performativité. Les théories de la performance ou de la performativité, d'après Federici, ont surfé sur l'idée que les identités étaient socialement construites pour dissoudre l'intrication des normes de genre à l'organisation de la division du travail :

La performance est un concept utile. Mais ses applications sont limitées, et partielles. [...] Le concept néglige le fait que le genre est le résultat d'un long processus de disciplinarisation et que les « normes » sont le produit de l'organisation et de la division du travail, de la configuration diverse des marchés du travail, de la structuration de la famille, de la sexualité, et du travail domestique. (p. 70)

Federici entame cette critique à partir de Beauvoir et la renforce avec l'aide de Sartre. Elle mobilise le concept de mauvaise foi développé dans L'Être et le $N e ́ a n t^{21}$ et le définit comme ce jeu ou cette performance attendue socialement par autrui en raison des conditions d'existence. Federici précise, encore par une note :

Utilisant l'exemple du garçon de café, de l'épicier, du commerçant, Sartre montre comment leur performance apparait comme un jeu, une cérémonie, quoique sérieuse, car le public réclame qu'ils réalisent leur condition [...]. « La mauvaise foi » pour Sartre entre en jeu quand nous oublions que nous ne sommes pas « ce sujet que $j$ 'ai à être ». Ce qui l'intéresse est la reconnaissance de notre propre capacité ontologique à transcender les identités que nous sommes appelés à incarner. (p. 153)

Par le concept sartrien de mauvaise foi, Federici impose une torsion à la théorie du genre : elle admet, quelques lignes plus loin et avec cette notion sartrienne 
à l'appui, qu'il y a bien des formes de performativité sociale. Elle accepte également de considérer que la construction sociale de l'identité femme est liée à des types de performance du genre. Cependant, performer ce que l'on a-à-être n'implique pas, d'après Federici, que nous devions renoncer à décrire les causes structurelles des oppressions de genre et de sexe. En insistant sur les formes de résistance aux assignations sociales, sur l'efficacité politique de certaines de ces catégories (que nous avons autant à performer individuellement qu'à manier collectivement en vecteur de lutte) et, enfin, sur les structurations économiques qui fondent les catégories du genre, à savoir la division sexuelle du travail, Federici produit une lecture de L'Être et le Néant qui agit comme une alliance dans son positionnement féministe contre les théories post-structuralistes. À revers du premier usage sartrien qui était mobilisé par Federici pour décrire les cadres de l'aliénation structurelle, la machinisation des corps et leurs conséquences subjectives, cette seconde apparition fait droit à la question de la lutte, ou plutôt de sa possibilité, depuis le cadre existentialiste ou depuis ce que Raphaël Gély nomme « une phénoménologie du jeu »22.

La description de l'ouvrière Dop semble encore une fois utile à ajouter à la discussion pour saisir l'intrication des deux notes, celle renvoyant à Huis Clos, l'autre à L'Être et le Néant. Federici saisit, avec et à partir de Sartre, l'ambiguité d'une analyse matérialiste de l'aliénation lorsqu'elle s'affronte à l'exigence de penser cette expérience à l'échelle du corps. L'ouvrière Dop semble bien aliénée jusque dans sa plus stricte intimité (sexualité, désir, rêverie) et, pourtant, Sartre continue de marquer l'écart inexorable qui subsiste car cette ouvrière a à être ce qu'elle est, c'est-à-dire ne l'est pas totalement. La distance marquée avec les théories de la performativité peut se reprendre à nouveaux frais : avoir-à-être ce qu'on est n'équivaut pas simplement à performer les assignations dont chacun.e a échu mais bien à habiter ce qui échoit comme position dans l'existence depuis l'expérience simultanée d'un écart et d'une relation constitutive entre monde et conscience, double expérience qui est inhérente à l'existentialisme sartrien.

La mauvaise foi sartrienne peut paraitre ambiguë en ce qu'elle mobilise le terme de jeu, voire l'idée de performance. Il faut comprendre pourquoi la référence au concept de mauvaise foi ne renforce pas l'hypothèse performative : l'exemple, lui aussi fameux, du garçon de café23 $n$ 'illustre pas, en réalité et si l'on en croit la remarque de Federici, le rôle social et le type de performance qu'il engendre mais bien la subsistance ou non d'une capacité d'écart aux positions sociales qui sont assignées aux corps, c'est-à-dire la subsistance de foyer de lutte. Cet écart est lié à des types de conduite en situation et se manifeste par le biais de corps qui, tout d'un coup, « débordent et éludent leur condition $»^{24}$. L'attachement de Federici à la mauvaise foi sartrienne se tisse 
autour de ce pouvoir de résistance; aucun corps n'est absolument réduit à sa situation et il fait subsister, même au sein des aliénations les plus profondes, des dimensions existentielles qui excèdent la situation en elle-même. Cet usage de Sartre s'avère précieux ; il révèle la teneur opérationnelle ou pragmatique des pensées féministes.

Federici approuve la position sartrienne et invite son.sa lecteur.trice à constater que « nous nous échappons » (p. 71). Tout corps est une puissance d'échappement ; c'est un territoire qui, même s'il est privé de toutes les manières et absolument des moyens de se défendre, résiste. Cultiver collectivement, par ce que l'autrice nomme un militantisme joyeux (p. 138), une puissance concrète, matérielle et organisée de lutte implique de faire passer ce qui de chaque corps résiste dans l'organisation politique de la révolte féministe et anticapitaliste. Par ce passage de l'expérience du corps à la lutte collective, de nouvelles possibilités de vie se déploient.

À l'entame de ce livre, Jules Falquet rappelait la centralité des corps dans certains mouvements féministes latino-américains qui articulent leurs luttes autour de la revendication « nuestra cuerpa » (p. 8) et les liens que tissait Federici avec ces mouvements sociaux. Par un autre montage philosophique, j'ai voulu redistribuer certains gestes philosophiques et appréhender le type de stratégies épistémologiques et politiques qu'ils véhiculent. L'enjeu est autant historique que pragmatique : il s'agit de rendre pensable ce que peuvent certaines généalogies philosophiques. Ce jeu de rapprochements entre Sartre et Federici montre comment la question du corps, une fois mise au cœur de sa discussion avec le marxisme, insiste sur l'actualité de pouvoir revendiquer notre corps comme objet/sujet de la lutte antipatriarcale, anticoloniale et anticapitaliste.

\section{Notes}

${ }^{1}$ La différence entre performance et performativité est traitée par Butler dans l'introduction qu'elle ajoute à l'édition de son livre Trouble dans le genre en 1999. Reprenant à son compte certaines critiques générées par la première édition en 1990, elle fait part d'un itinéraire critique sur son propre concept de performativité. Elle stipule que l'idée qu'elle se faisait de la performativité a changé avec le temps et que ses travaux des années qui ont précédé ont eu pour objet de clarifier et de réviser la théorie de la performativité. Assumer le caractère mouvant de sa pensée de la performativité la rend difficilement définissable. Notons, faute de pouvoir procéder à l'analyse détaillée du concept, «l'idée que le genre est performatif a été conçue pour montrer que ce que nous voyons dans le genre comme une essence intérieure est fabriqué à travers 
une série ininterrompue d'actes, [...]. » (Butler, J., Trouble dans le genre. Le féminisme et la subversion de l'identité, Paris, Éditions La Découverte, 2006, p. 36) Et Butler de préciser : " Il arrive que Trouble dans le genre laisse croire que le genre est une simple invention de soi ou que le sens psychique d'une présentation genrée peut se lire directement à sa surface. Avec le temps j'ai nuancé ces deux postulats. De plus, ma théorie offre une interprétation tantôt plus linguistique tantôt plus théâtrale de la performativité. [...] Dans Le Pouvoir des mots, j'ai cherché à montrer comment l'acte de parole relevait à la fois de la performance (et qu'il comporte donc une dimension théâtrale, qu'il est présenté à un public, sujet à interprétation) et du langage induisant un ensemble d'effets par sa relation d'implication avec les conventions linguistiques » (Ibid., p. 48-49). Cette reprise critique et cette distinction sont éludées par Federici lorsqu'elle s'oppose à Butler et, plus frontalement, à ses héritiers.

${ }^{2}$ Voir notamment l'article datant de 1982 réédité dans cet ouvrage : S. Federici \& G. Caffenttzis, « Mormons in Space Revisited », Midnight Notes 2, n 1, 1982, p. 3 12.

${ }^{3}$ Réflexion principalement issue des discussions qui ont suivi un cycle de trois conférences données au California Institute of Integral Studies en 2015.

${ }^{4}$ K. Marx, L'idéologie Allemande, trad. Molitor, Ire partie, p. 225, cité dans Sartre, J.P., Critique de la Raison dialectique, Tome 1. Théorie des ensembles pratiques, Paris, Gallimard, 1985 (1960), p. 341.

${ }^{5}$ S. Federici, Caliban et la Sorcière, Genève, Entremonde, 2017.

${ }^{6}$ A. Davis, « Surrogates and Outcast Mothers : Racism and Reproductive Policies in the Nineties ", dans The Angela Y. Davis Reader, édité par Joy James, Malden, MA, Blackwell, 1998, p. 210-221.

${ }^{7}$ D. Roberts, Killing the Black Body: Race, Reproduction and the Meaning of Liberty, New-York, Vintage Books, (1997) réed. 2017.

${ }^{8}$ K. Marx, Le Capital, livre 1, Paris, Presses Universitaires de France, 2009, p. 445.

9 J.-P. Sartre, Huis Clos, Paris, Gallimard, Folio, 1976.

${ }^{10}$ J.-P. Sartre, Critique de la Raison dialectique, Tome 1. Théorie des ensembles pratiques, Paris, Gallimard, 1985 (1960).

11 J.-P. Sartre, Ibid., p. 341.

${ }^{12}$ La Gauche, Les Temps Modernes, n 112, 1955.

13 J.-P. Sartre, Critique de la Raison dialectique, Tome 1, p. 342-343.

14 J.-P. Sartre, Qu'est-ce que la subjectivité ?, Paris, Les Prairies Ordinaires, 2013, p. 67.

15 J.-P. Sartre, La Transcendance de l'Ego, Paris, Vrin, 1998.

16 J.-P. Sartre, L'existentialisme est un humanisme, Nagel, Paris, 1946, p. 37.

${ }^{17}$ R. Gély, Imaginaire, Perception, Incarnation. Exercice phénoménologique à partir de Merleau-Ponty, Henry et Sartre, Bruxelles, Peter Lang, 2012, p. 444. 
${ }^{18}$ G. Cormann, « Existenz, Körpertechniken und Gewalt bei Sartre. Skizzen zu einer politischen Anthropologie der Emotionen », p. 9, cité dans R. Gély, Imaginaire, Perception, Incarnation. Exercice phénoménologique à partir de Merleau-Ponty, Henry et Sartre, Bruxelles, Peter Lang, 2012, p. 494.

${ }^{19}$ S. de Beauvoir, Le Deuxième sexe II, Paris, Gallimard, 1949, p. 1.

${ }^{20}$ J. Butler, Trouble dans le genre. Le féminisme et la subversion de l'identité, Paris, Éditions La Découverte, 2006, p. 29 : «Trouble dans le genre prend racine dans la French Theory, qui est elle-même une drôle de construction américaine. »

${ }^{21}$ J.-P. Sartre, L'Être et le Néant, Paris, Gallimard, 1982 (1943).

${ }^{22}$ R. Gély, Imaginaire, Perception, Incarnation, p. 444.

${ }^{23}$ J.-P. Sartre, L'Être et le Néant, p. 96.

24 Ibid.

Clémence Mercier Université de Liège 